\title{
Splice and Dice: Intronic microRNAs, Splicing and Cancer
}

\author{
Alex C. H. Wong ${ }^{1,2}$ and John E. J. Rasko ${ }^{1,2,3, *(D)}$ \\ 1 Gene \& Stem Cell Therapy Program, Centenary Institute, University of Sydney, Camperdown 2050, Australia; \\ a.wong@centenary.org.au \\ 2 Sydney Medical School, University of Sydney, Sydney 2006, Australia \\ 3 Cell and Molecular Therapies, Royal Prince Alfred Hospital, Camperdown 2050, Australia \\ * Correspondence: j.rasko@centenary.org.au
}

\section{check for}

updates

Citation: Wong, A.C.H.; Rasko, J.E.J. Splice and Dice: Intronic microRNAs, Splicing and Cancer. Biomedicines 2021, 9, 1268. https://doi.org/ $10.3390 /$ biomedicines 9091268

Academic Editor: Francesca Lovat

Received: 30 August 2021

Accepted: 16 September 2021

Published: 19 September 2021

Publisher's Note: MDPI stays neutral with regard to jurisdictional claims in published maps and institutional affiliations.

Copyright: (c) 2021 by the authors. Licensee MDPI, Basel, Switzerland. This article is an open access article distributed under the terms and conditions of the Creative Commons Attribution (CC BY) license (https:// creativecommons.org/licenses/by/ $4.0 /)$.

\begin{abstract}
Introns span only a quarter of the human genome, yet they host around $60 \%$ of all known microRNAs. Emerging evidence indicates the adaptive advantage of microRNAs residing within introns is attributed to their complex co-regulation with transcription and alternative splicing of their host genes. Intronic microRNAs are often co-expressed with their host genes, thereby providing functional synergism or antagonism that is exploited or decoupled in cancer. Additionally, intronic microRNA biogenesis and the alternative splicing of host transcript are co-regulated and intertwined. The importance of intronic microRNAs is under-recognized in relation to the pathogenesis of cancer.
\end{abstract}

Keywords: microRNA; introns; cancer; alternative splicing; mirtrons; splicing factors; DROSHA

\section{Introduction}

MicroRNAs (miRNAs) are short single-stranded non-coding RNA of approximately 22 nucleotides (nt) in length. First discovered in 1993 in C. elegans [1], miRNAs provide an evolutionally conserved mechanism by which gene downregulation is mediated [2]. MiRNAs, together with the Argonaute proteins, form the RNA-induced silencing complex (RISC) through which miRNAs target messenger RNA (mRNA) via base-pair complementarity [3]. Targets with high base-pair complementarity induce mRNA transcript degradation and a strong silencing effect, whereas targets with partial complementarity promote translational repression and a milder effect $[4,5]$. In this way, a single miRNA can exert widespread effects by downregulating multiple functionally-related genes [6]. MiRNAs provide a powerful modulation of biological pathways affecting cancer development, progression, and treatment resistance via oncogenic or tumor suppressor roles [7-9].

Introns are segments of genetic code that are typically removed during or after transcription of RNA from DNA in a process termed splicing. As they were observed to be generally removed from mature messenger RNA (mRNA), introns were originally regarded as "junk" genetic material [10]. Advances in high-throughput sequencing and bioinformatics have revealed introns as evolutionarily conserved regulators of gene expression via multiple mechanisms [11-13]. Alternative splicing of introns occurs in an estimated 92\% of human genes, allowing each gene to transcribe multiple combinations of exons which greatly expand proteomic diversity [14]. Intron retention, whereby introns are preserved in mature mRNA, adds an additional layer of gene regulation via post-transcriptional downregulation either through nuclear detention or cytoplasmic nonsense-mediated decay of mRNA $[15,16]$. Introns can also enhance gene expression by modulating the rate of gene transcription, and regulate the nuclear export and stability of mRNA transcripts [13].

Introns also harbor miRNA as well as other non-protein-coding genomic elements including long non-coding RNAs, small nucleolar RNAs, small interfering RNAs and Piwi-interacting RNAs [17]. Although miRNAs can also be located across exons or splice junctions, intronic miRNAs are the most common form of intragenic miRNAs, representing around $60 \%$ of all known miRNAs [18]. Given that introns only span around $25 \%$ of the 
genome [19], the predilection of miRNAs to reside within introns is worthy of further study. In contrast to intergenic miRNAs that are transcribed via independent promoters, intronic miRNAs are often transcribed together with their host genes using the same promoters; in this situation, both are derived from the same molecule of pre-mRNA [20-22]. Co-expression of intronic miRNAs and their host genes allow an additional layer of functional complexity whereby intronic miRNAs can either synergize or antagonize host gene functions [23,24]. Moreover, intronic miRNA processing can cooperate or compete with splicing of its host gene in ways that are yet to be fully characterized [25]. In this review, we explore the current knowledge of the biogenesis of intronic miRNAs, their regulation with respect to interactions with intron splicing, and their implications to cancer biology.

\section{Biogenesis of Intronic miRNAs}

Most miRNAs are generated via the canonical miRNA pathway (Figure 1A) [26]. The initial substrate is the primary miRNA (pri-miRNA), a linear molecule of RNA directly transcribed from DNA. Pri-miRNA transcription is most often mediated by RNA polymerase II, although some are transcribed via RNA polymerase III [27]. Characteristically, pri-miRNAs contain regions of self-complementarity that form hairpin secondary structures critical for downstream processing [28]. Two stretches of self-complementary RNA base-pair, often imperfectly, to form the hairpin stem, with the intervening conserved sequence of bases forming the hairpin loop [29]. This hairpin recruits the microprocessor complex which consists of DiGeorge Syndrome Critical Region 8 (DGCR8) and the ribonuclease III DROSHA [30]. The hairpin stem of a canonical pri-miRNA is typically around $33 \mathrm{nt}$ in length, of which DROSHA cleaves to remove the $11 \mathrm{nt}$ of the lower stem, producing precursor miRNA (pre-miRNA) [30].

DROSHA cleavage via its ribonuclease III activity results typically in pre-miRNA with a 2 nt 3 '-overhang at its base, which is in turn recognized by Exportin 5 (Figure 1E) [31]. Binding by Exportin 5 facilitates the cytoplasmic export of pre-miRNA [32]. Following cytoplasmic export, the pre-miRNA hairpin loop recruits DICER, which cleaves the loop thereby producing a miRNA duplex (Figure 1F) [33]. This duplex is then loaded onto Argonaute proteins whereby strand selection takes place (Figure 1G) [34]. The "passenger" strand is unwound and ejected from the Argonaute complex and is subsequently degraded. The retained "guide" strand programs the Argonaute to hone in on transcripts of its target genes, leading to formation of the RISC (Figure 1H) [34]. The RISC binds miRNA target sites which are typically situated at $3^{\prime}$-untranslated regions (UTRs) of protein-coding transcripts but can also reside on $5^{\prime}$-UTRs and protein coding regions (Figure 1I) [35]. RISC binding can either act to promote mRNA degradation or inhibit mRNA translation $[4,5]$.

\subsection{Co-Transcriptional Processing of Intronic miRNAs}

Intragenic miRNAs, including intronic miRNAs, are expressed at levels that correlate with their host genes [20]. This substantiate the idea that, although an estimated $35-50 \%$ of intronic miRNAs can also be transcribed via independent promoters $[27,36]$, the majority were derived from the same strand of RNA as that of the spliced host gene transcripts [20]. Intron splicing results in the formation of a circular molecule of RNA with a short tail, known as an intron lariat. Initially, it was thought that intron splicing and subsequent debranching of the intron lariat by Debranching RNA Lariats 1 (DBR1) was required before its resident miRNAs underwent DROSHA processing [37]. Later studies showed that microprocessing of pri-miRNA was predominantly co-transcriptional, and intronic miRNAs were microprocessed concurrently with intron splicing [22]. DGCR8/DROSHA binds to and cleaves the pri-miRNA hairpin directly from the intron loop whilst the flanking exons and the intervening intron are tethered to the committed spliceosome (Figure 1B) [21,22]. Microprocessing of intronic miRNA thereby results in a disconnected intron which is subsequently degraded by exonucleases that facilitate the completion of splicing [38]. Thus, the interconnectivity between microprocessing and intron splicing 
implies an overarching complex mechanism that co-regulates both pre-miRNA biogenesis and splicing.
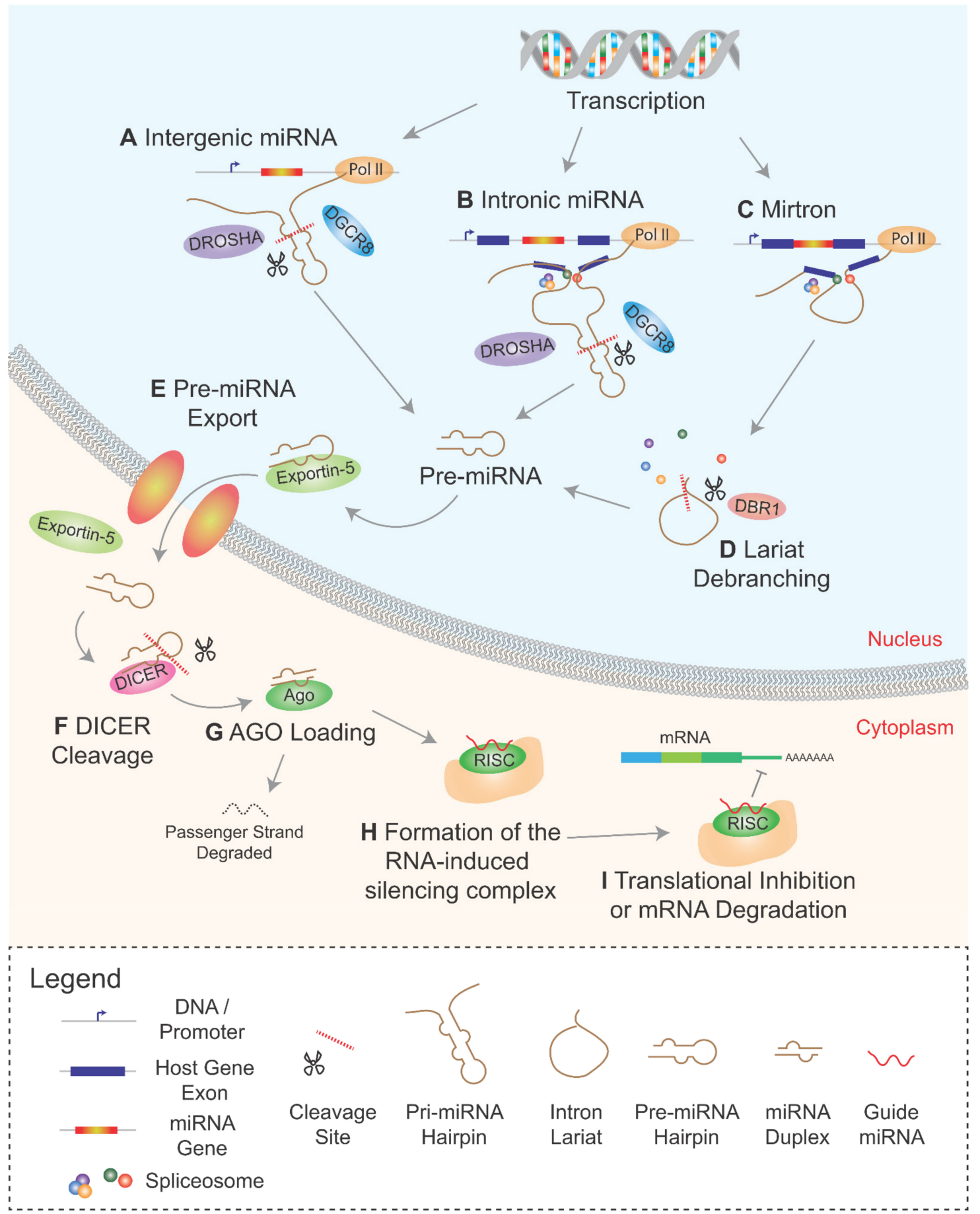

Figure 1. Overview of miRNA Biogenesis. (A) Intergenic primary miRNAs (pri-miRNAs) undergo co-transcriptional microprocessing via DGCR8/DROSHA to produce precursor miRNA (pre-miRNA). (B) In intronic miRNAs, microprocessing occurs during intron commitment for splicing and generally completes before the intron is spliced. (C) Mirtrons are a special class of intronic miRNAs whereby pre-miRNAs are derived directly from intron splicing and (D) lariat debranching by DBR1. (E) Canonical and mirtron pre-miRNAs join a common pathway of Exportin-5 mediated cytoplasmic export, after which (F) DICER cleavage produces a miRNA duplex. (G) miRNA duplexes are loaded onto Argonaute (Ago) proteins whereby strand selection occurs. (H) Retention of the miRNA guide strand by Ago is critical to the formation of the RNA induced silencing complex (RISC) which (I) targets protein-coding mRNAs promoting either transcript degradation or inhibiting translation. Pol II = RNA Polymerase II. 


\subsection{Mirtrons and the Non-Canonical miRNA Pathway}

Around 500 human intronic miRNAs, termed mirtrons, bypass DROSHA-dependent microprocessing [39]. Instead, mirtron pre-miRNAs are derived directly from intron splicing and intron lariat debranching (Figure 1C/D) [39,40]. Mirtrons contain sequences that self-complement to form the $\sim 22 \mathrm{nt}$ hairpin stems analogous to DGCR8/DROSHA mediated cleavage products of canonical miRNA. This contrasts with the 33- nt hairpin of typical canonical DROSHA-dependent miRNAs [41]. Debranched mirtrons are analogous to canonical pre-miRNAs and join the canonical pathway at the cytoplasmic export stage by Exportin-5 (Figure 1E). Mirtrons are subsequently processed by DICER in the same manner as canonical miRNAs [41].

Mirtrons, first identified in invertebrates, were observed to contain the precise 2- nt 3'-AG overhang created by their splice acceptor motifs, identical to pre-miRNA derived from DROSHA microprocessing [41]. In contrast, mammalian mirtrons did not strictly have these 2-nt overhangs, but instead have both $5^{\prime}-G$ and $3^{\prime}-G$ overhangs [42]. Such mirtrons are also exported by the canonical pathway since Exportin- 5 accepts a broader range of hairpin substrates than the classical 3'-AG overhangs [42,43]. Additionally, mirtron premiRNAs are not strictly bound by their intron boundaries. Mirtrons can be "tailed" by extra nucleotides at their $5^{\prime}$ - or $3^{\prime}$-ends (or both), which are subsequently cleaved by nuclear exonucleases prior to pre-miRNA export [44]. In $3^{\prime}$-tailed mirtrons, this occurs via the RNA exosome [45], in which the mirtron is protected from exonucleolytic degradation due to the secondary structure of their hairpins $[44,46] .5^{\prime}$-tailed mirtrons are presumably trimmed via another yet-to-be characterized mechanism prior to nuclear export. $5^{\prime}$-tailed mirtrons are the most abundant type of mirtrons (with 420 annotated), followed by canonical mirtrons (33 annotated) and $3^{\prime}$-tailed mirtrons (18 annotated) [39].

\subsection{Comparisons and Contrasts between Mirtrons and Canonical Intronic miRNAs}

Mirtrons represent the largest class of non-canonical miRNAs. They are structurally distinct from canonical miRNAs, although the differences are more complex and do not solely depend on a single parameter [47]. A recent machine-learning approach showed that, compared to canonical miRNAs, mirtrons have a $5^{\prime}$-arm richer in guanine and thereby $3^{\prime}$-arm richer in cytosine [47]. Also, mirtrons have higher free energy levels and shorter hairpin lengths [47].

The DROSHA-independent, splicing-dependent nature of mirtron biogenesis affords several advantages compared with canonical miRNAs. First, mirtrons are not affected by saturation of the microprocessor. DROSHA is a multi-functional protein and is involved also in mRNA destabilization, transcriptional regulation, and maintaining genome integrity [48]. Impairment of DROSHA microprocessor activity, as occurs in mutant tumor protein p53, is implicated in tumorigenesis [49]. Additionally, amplification of oncogenic pri-miRNAs saturates the microprocessor, leading to indirect downregulation of other DROSHA-dependent miRNAs [50]. Secondly, mirtrons evolve more quickly than canonical miRNAs [2]. This may in part be attributed to the fact that their expression only requires one cleavage event (DICER) instead of two [51]. Thus mirtrons require shorter hairpins and consequently a shorter stretch of self-complementary sequences than conventional miRNAs [51]. From an evolutionary perspective, mirtrons are younger and less conserved across species. For example, Wen and colleagues identified 478 and 488 mirtrons in human and mouse, respectively. Of these, only 13 mirtrons were conserved [39].

Mirtrons are less abundant than canonical miRNAs and the vast majority of mirtrons have yet to be functionally characterized. However, a small number of mirtrons play important oncogenic or tumor suppressor roles in multiple cancers. A list of the most well-characterized mirtrons and their roles in cancer are summarized in Table 1. 
Table 1. Top mirtrons in cancer.

\begin{tabular}{|c|c|c|c|c|}
\hline Mirtron & Type & Host Gene and Intron & Validated Gene Targets & Cancer \\
\hline$h s a-m i R-877$ & Mirtron & $\begin{array}{l}A B C F 1 \\
\text { Intron } 12\end{array}$ & $\begin{array}{c}\text { ACP5 [52], AQP3 [53], ATXN7L3 [54], } \\
\text { CCNA2 [55], CD274 [56], CDK14 [57], } \\
\text { CDKN2A (upreg) [58], FGF2 [59], } \\
\text { FOXM1 [60], FOXP4 [61], IGF1R [62], } \\
\text { MACC1 [63], MTDH [64], PIK3R3 [65], } \\
\text { PMEPA1 [66], STARD13 [67], SUZ12 [68], } \\
\text { TLR4 [69], VEGFA [70] }\end{array}$ & $\begin{array}{c}\text { Bladder (TS) [58], Cervical (TS) [54,59,63], } \\
\text { Colorectal (TS) [64], Gastric } \\
\text { (TS) [53,56,70], Glioma (Onc) [69], } \\
\text { Glioma (TS) [68], Laryngeal (TS) [61], } \\
\text { Liver (TS) [57,60,65], Lung (TS) [52,55,62], } \\
\text { Oesophageal (TS) [66], Pancreatic } \\
\text { (Onc) [67] }\end{array}$ \\
\hline hsa-miR-1224 & Mirtron & $\begin{array}{l}V W A 5 B 2 \\
\text { Intron } 17\end{array}$ & $\begin{array}{c}\text { CREB1 [71], ELF3 [72], ETV1 [73], } \\
\text { FAK [74], KLF3 [75], PGM5 [76], } \\
\text { PLK1 [77], RSF1 [78], SLC29A3 [79], } \\
\text { SP1 [80], SND1 [81,82], TGFBR2 [83], } \\
\text { TNS4 [84], }\end{array}$ & $\begin{array}{c}\text { Breast (Onc) [76], Colorectal (TS) [80], } \\
\text { Gastric (TS) [74,78], Glioma (TS) [71,83], } \\
\text { Lung (TS) [73,75], Oesophageal (TS) [84], } \\
\text { Osteosarcoma (TS) [77], Ovarian } \\
\text { (TS) [81], Pancreatic (TS) [72], Prostate } \\
\text { (TS) [82], Rectal (TS) [79] }\end{array}$ \\
\hline hsa-miR-1226 & Mirtron & $\begin{array}{l}\text { DHX30 } \\
\text { Intron } 20\end{array}$ & $\begin{array}{c}\text { AKT1 [85], AQP5 [86], DUSP4 [87], } \\
\text { ERBB2 [85], ITGB1 [88], MUC1 [89], } \\
\text { PIK3R2 [85] }\end{array}$ & Breast (TS) $[85,86,89]$, Liver (TS) $[87,88]$, \\
\hline hsa-miR-1227 & Mirtron & $\begin{array}{l}\text { PLEKHJ1 } \\
\text { Intron } 1\end{array}$ & IRF2 [90], MAPK13 [91], SUPT16H [92] & $\begin{array}{l}\text { Endometrial (TS) [91], Lung (TS) [92], } \\
\text { Osteosarcoma (Onc) [90], }\end{array}$ \\
\hline hsa-miR-1228 & Mirtron & $\begin{array}{l}L R P 1 \\
\text { Intron } 48\end{array}$ & $\begin{array}{c}\text { CSNK2A2 [93], MIF [94], MMP14 [95], } \\
\text { SCAI [96,97], SOX17 [98], TCF21 [99], } \\
\text { TP53 [100,101], }\end{array}$ & $\begin{array}{c}\text { Breast (Onc) [96,98], Gastric (TS) [93-95], } \\
\text { Liver (Onc) [101], Lung (Onc) [99], } \\
\text { Osteosarcoma (Onc) [97], Ovarian } \\
\text { (Onc) [100] }\end{array}$ \\
\hline hsa-miR-1229 & Mirtron & $\begin{array}{l}\text { MGAT4B } \\
\text { Intron } 1\end{array}$ & $\begin{array}{l}\text { APC [102], GSK3B [102], HIPK2 [103], } \\
\text { ICAT [102], ITGB8 [104], MTOR [105], }\end{array}$ & $\begin{array}{c}\text { Breast (Onc) [102], Colorectal (Onc) [103], } \\
\text { Glioma (TS) [104,105], }\end{array}$ \\
\hline hsa-miR-1236 & Mirtron & $\begin{array}{l}R D B P \\
\text { Intron } 7\end{array}$ & $\begin{array}{c}\text { AFP [106], ATG7 [107], CHD4 [108], } \\
\text { CDKN1A (upreg) [109], HDAC3 [110], } \\
\text { HMGB1 [111], HOXB7 [112,113], } \\
\text { KLF8 [114], MTA2 [115], SENP1 [110], } \\
\text { SLC9A1 [116], TPT1 [117], TRIM37 [118], } \\
\text { ZEB1 [119,120], }\end{array}$ & $\begin{array}{l}\text { Breast (TS) [108,116,120], Cervical } \\
\text { (TS) [118], Colorectal (TS) [112], Gastric } \\
\text { (TS) [111,115], Glioma (TS) [113], Lung } \\
\text { (TS) [107,114,117], Liver (TS) [106], } \\
\text { Kidney (TS) [109], Ovarian (TS) [119], }\end{array}$ \\
\hline hsa-miR-937 & $\begin{array}{l}3^{\prime} \text {-tailed } \\
\text { mirtron }\end{array}$ & $\begin{array}{l}S C R I B \\
\text { Intron } 29\end{array}$ & $\begin{array}{l}\text { APAF1 [121], CCRL2 [122], FOXQ1 [123], } \\
\text { INPP4B [124], SOX17 [125], TIMP3 [126], }\end{array}$ & $\begin{array}{l}\text { Breast (Onc) [121,125], Breast (TS) [123], } \\
\text { Colorectal (Onc) [126], Lung (Onc) [124], }\end{array}$ \\
\hline hsa-miR-939 & $\begin{array}{l}5^{\prime} \text {-tailed } \\
\text { mirtron }\end{array}$ & $\begin{array}{l}\text { CPSF1 } \\
\text { Intron } 4\end{array}$ & $\begin{array}{c}\text { APC2 [127], ARHGAP4 [128], } \\
\text { BCL2L1 [129,130], CDH5 [131], } \\
\text { HDGF [132], IGF1R [133], JUNB [134], } \\
\text { LIMK2 [135], NGFR [136], SLC34A2 [137], } \\
\text { TIMP2 [138], }\end{array}$ & $\begin{array}{c}\text { Breast (Onc) [131], Colorectal } \\
\text { (TS) [130,135], Gastric (TS) [137], Lung } \\
\text { (Onc) [138], Lymphoma (TS) [134], } \\
\text { Ovarian (Onc) [127], Osteosarcoma } \\
\text { (TS) [133], Pancreatic (Onc) [128], } \\
\text { Prostate (TS) [132], }\end{array}$ \\
\hline hsa-miR-1292 & $\begin{array}{l}5^{\prime} \text {-tailed } \\
\text { mirtron }\end{array}$ & $\begin{array}{l}\text { NOP56 } \\
\text { Intron } 11\end{array}$ & $D E K[139]$ & Gastric (TS) [139], \\
\hline hsa-miR-1976 & $\begin{array}{l}5^{\prime} \text {-tailed } \\
\text { mirtron }\end{array}$ & $\begin{array}{l}\text { RPS6KA1 } \\
\text { Intron } 6\end{array}$ & PIK3CG [140], PLCE1 [141], & Breast (TS) [140], Lung (TS) [141], \\
\hline$h s a-m i R-4728$ & $\begin{array}{l}5^{\prime} \text {-tailed } \\
\text { mirtron }\end{array}$ & $\begin{array}{c}E R B B 2 \\
\text { Intron } 25\end{array}$ & $\begin{array}{c}\text { CAV1 [142], COL1A2 [142], EBP1 [143], } \\
\text { ESR1 [144], MST4 [145], PAPD5 [146], } \\
\text { THBS2 [142] }\end{array}$ & $\begin{array}{c}\text { Breast (Onc) [143,146], Breast (TS) [145], } \\
\text { Colorectal (TS) [142], Lung (TS) [147], }\end{array}$ \\
\hline$h s a-m i R-6838$ & $\begin{array}{l}5^{\prime} \text {-tailed } \\
\text { mirtron }\end{array}$ & $\begin{array}{l}\text { POLM } \\
\text { Intron } 10\end{array}$ & GPRIN3 [148], WNT3A [149], & Breast (TS) [149], Gastric (TS) [148] \\
\hline$h s a-m i R-6852$ & $\begin{array}{l}5^{\prime} \text {-tailed } \\
\text { mirtron }\end{array}$ & $\begin{array}{l}\text { TLN1 } \\
\text { Intron } 24\end{array}$ & $\begin{array}{c}\text { FOXJ1 [150], LEF1 [151], ICAM1 [152], } \\
\text { TCF7 [153], }\end{array}$ & $\begin{array}{l}\text { Colorectal (TS) [153], Gastric (TS) [150], } \\
\text { Glioma (TS) [151], Liver (TS) [152] }\end{array}$ \\
\hline
\end{tabular}

Top cancer-relevant mirtrons, with mirtron type and host intron location as annotated by Wen et al. [39]. Target genes are downregulated by their respective mirtrons; except those denoted "upreg" to indicate that the target gene is upregulated by non-canonical mechanisms. "TS" and "Onc" denote tumor suppressor and oncogenic roles, respectively, in their corresponding tumor types.

\section{Interplay between miRNA Processing and the Spliceosome}

The enrichment of miRNA residence in introns and the dependence of the microprocessor complex on transcription [22] suggest that intronic miRNA processing and intron splicing are co-regulated processes. Splicing is performed by the spliceosome, a dynamic mega-dalton complex of five ribonucleoproteins and hundreds of other auxiliary proteins [154]. The spliceosome forms as splicing factors are recruited stepwise onto nascent 
RNA initiated by splice site recognition [155]. Splicing progresses as the spliceosome undergoes the necessary conformational changes to ligate exons and excise the intervening intron [154]. RNA-bound splicing factors modulate splice site choice by enhancing or hindering splice site recognition [156]. Emerging evidence indicates that the microprocessor interacts with the spliceosome $[38,157]$, substantiating the idea that splicing factors not only modulate splice site choice and alternative splicing, but also the expression of intronic and other intragenic miRNAs. In this section, we explore the role of the spliceosome and alternative splicing on regulating miRNA biogenesis.

\subsection{Kinetic Regulation of Microprocessing and Splicing}

The rate of RNA transcription is known to influence the outcome of alternative splicing, whereby a slower transcription rate favors the inclusion of alternate exons, and a fast rate promotes exon skipping [158]. Likewise, transcriptional stalling also facilitates miRNA biogenesis. Minigene studies have shown that increased nascent RNA retention at transcription sites induces higher miRNA expression [159]. Transcriptional stalling can be induced by exons flanking intronic miRNAs, or by removal of its polyadenylation signal [159]. Consistent with this, miRNA expression is enhanced by spliceostatin-mediated splicing inhibition [157].

More recently it has been shown that increased DNA methylation near miRNA hairpins facilitate microprocessing by inducing transcriptional stalling (Figure 2A) [160]. Methylated $\mathrm{CpG}$ residues bind Methyl-CpG Binding Protein 2 (MeCP2) leading to stalling of RNA polymerase II, which in turn enhances microprocessing [160]. MeCP2 is known to interact with DGCR8 and may facilitate recognition of miRNA hairpins [160,161]. Interestingly, we and others have shown that DNA methylation also regulates intron retention and other forms of alternative splicing $[162,163]$. Higher methylation levels at alternate exons promote their inclusion [162], whereas lower levels of methylation in flanking exons promote intron retention [163]. In intron retention, decreased methylation leading to loss of MeCP2 binding impairs the recruitment of the splicing factor Transformer 2 Beta Homolog (TRA2B) [163]. Taken together, DNA methylation modulates both alternative splicing and miRNA processing via MeCP2 binding, which induces both transcriptional stalling and modulating recruitment of co-factors.

However, transcriptional stalling may not adequately account for the observed changes in miRNA expression. Instead, transcriptional stalling facilitates the context-dependent recruitment of microprocessor components, in coordination or competition with recruitment of other RNA binding factors that modulate splicing [164]. Supporting this, the presence of flanking splice sites does not always facilitate microprocessing. For example, miR-211 microprocessing was dependent only on the presence of its upstream $5^{\prime}$-splice site, whereas miR-204 microprocessing was dependent on both $5^{\prime}$ - and $3^{\prime}$-splice sites [165]. The context dependent modulation of miRNA processing by auxiliary splicing factors is addressed in the next section.

\subsection{Splicing Factors Regulating Microprocessing}

RNA-bound splicing factors modulate splice site choice by enhancing or hindering splice site recognition. Many classes of splicing factors exist, and two major classes are well characterized. The serine-arginine (SR) proteins generally promote splice site recognition and exon inclusion, while heterogenous nuclear ribonucleoproteins (hnRNPs) generally promote exon skipping [156]. Additional complexities can arise when, for example, splicing factors regulate alternative splicing of other splicing factor genes [166]. This section discusses the role that splicing factors play in modulating the microprocessing of specific intronic miRNA. 


\section{A Transcriptional Stalling (DNA Methylation)}

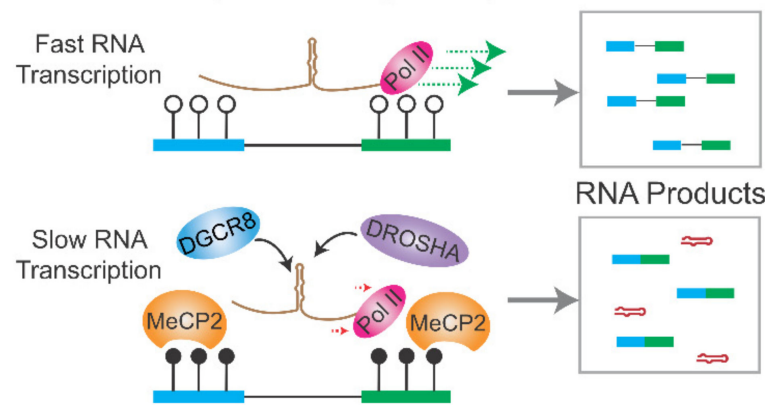

C Splicing Factor Microprocessor Facilitation
B Splicing Factor Recruitment

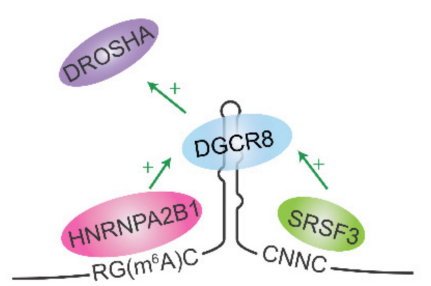

D Splicing Factor Antagonism
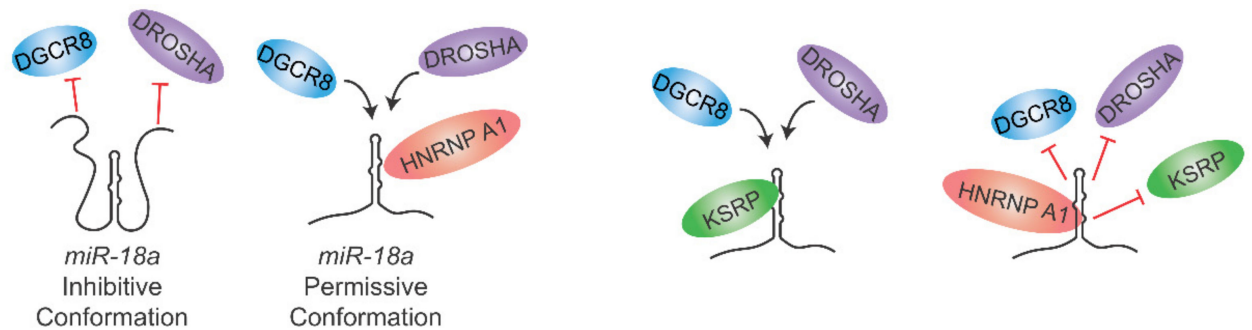

E Splice Site

Overlapping miRNAs
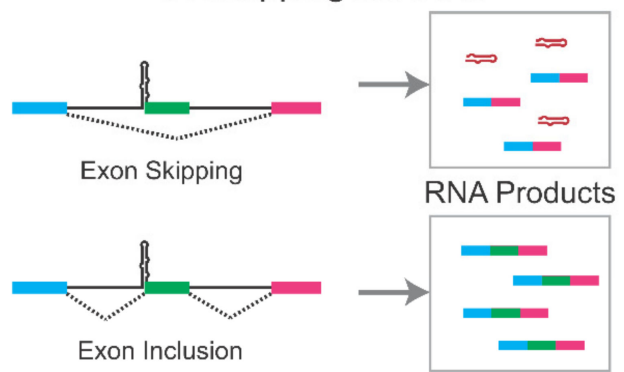

F Host Gene Decoupling via Alternative Polyadenylation

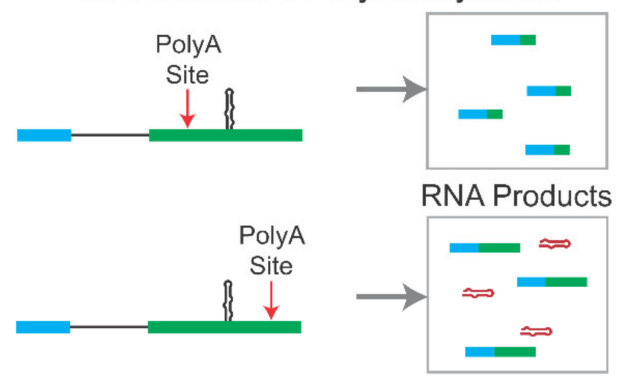

G Transcript Localization via Intron Retention

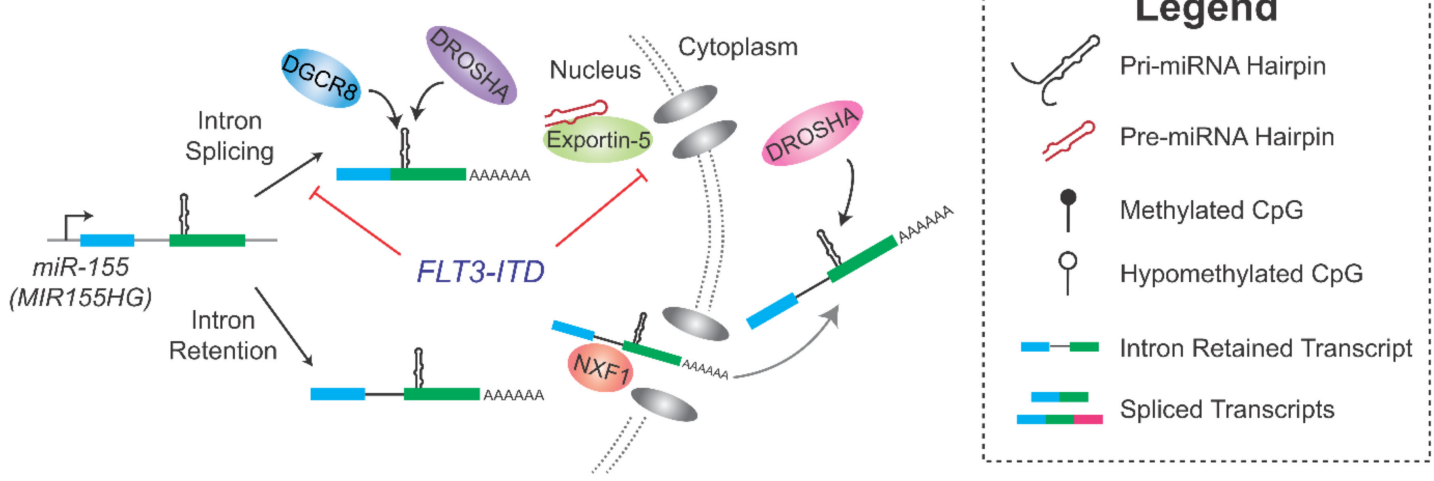

Figure 2. Examples of Splicing Regulation of Intronic and Intragenic miRNAs. (A) Transcriptional stalling (as occurs due to DNA hypermethylation) promotes microprocessing of intronic miRNAs. (B) Splicing factor binding adjacent to miRNA hairpins promotes recruitment of DGCR8/DROSHA. (C) Splicing factor binding to miRNA hairpins can alter pri-miRNA accessibility to microprocessor binding. (D) Splicing factors compete for binding to miRNA hairpins to facilitate or hinder pri-miRNA microprocessing. (E) Inclusion of alternate exons inhibits the expression of splice site overlapping miRNAs. (F) Alternative polyadenylation decouples miRNA/host gene expression. (G) Intron retention modulates pri-miRNA localization. Refer to the text (Section 3) for details. Pol II = RNA Polymerase II; PolyA = polyadenylation. 
Of the SR proteins, Serine and Arginine Rich Splicing Factor 1 (SRSF1) was the first splicing factor that was shown to also regulate miRNA processing. Wu et al. identified 4 miRNAs $(m i R-7, m i R-29 b, m i R-221$, and $m i R-222)$ which exhibits increased expression following SRSF1 overexpression [167]. SRSF1 regulates the microprocessing of miR-7, mediated by an SRSF1 binding motif on its lower stem [167]. Moreover, miR-7 directly targets the 3'-UTR of SRSF1, forming a negative feedback loop to regulate SRSF1 levels [167]. More recently, SRSF1 regulation of miR-222 was shown to occur via a different mechanism [168]. The miR-222 locus overlaps a splice site of a 44-nt mini-exon of its host gene, MIR222HG. SRSF1 binding to the mini-exon increases exon inclusion thereby precluding the production of $m i R-222$. Blocking the SRSF1 binding site to the mini-exon increases miR-222 expression, whereas blocking the SRSF1 binding site in the miR-222 stem loop increases spliced MIR222HG expression [168]. Taken together, SRSF1 binding sites can either enhance or impair microprocessing depending on the context of their binding sites.

Mirtrons are formed directly from intron splicing and thus their biogenesis should be expected to be regulated by splicing factors. Consistent with this, SRSF1 overexpression significant increases $m i R-1229-3 p$ expression, whereas SRSF2 overexpression significantly increases $m i R-1227-3 p$ and $m i R-1229-3 p$ expression [169]. The largest effects were associated with splice enhancer motifs for SRSF1 and SRSF2 in their corresponding proximal exons, suggesting splice enhancer SR proteins may play a direct role in regulating mirtron expression through enhancing splice site recognition [169].

SRSF3 also enhances the microprocessing of a subset of miRNAs (Figure 2B). SRSF3 binds a CNNC motif adjacent to the basal junction of the pri-miRNA stem [170]. SRSF3 binding to this motif enhances the recruitment of DROSHA in a spatially-dependent context, whereby DROSHA cleavage in miRNAs with CNNC motifs were only enhanced when the motif was located $\sim 17 \mathrm{nt}$ from the DROSHA cleavage site [170]. In this manner, SRSF3 regulates a specific subset of miRNAs, including miR-16, miR-30a and miR-142 [170,171].

Various hnRNPs have been implicated in modulating miRNA processing. The first such hnRNP to be identified was the splicing factor hnRNP A1. This factor binds to, and facilitates, the specific processing of miR-18a [172], which is the second member of the $m i R-17-92$ cluster of miRNAs. The miR-17-92 cluster is a polycistronic locus of 6 miRNA residing mostly on the third intron of its host gene MIR17HG (formerly known as C13orf25). It is the first locus of polycistronic miRNAs to be classified as oncogenic and was the first classified "oncomiR" [173], being first identified as a region of amplification in Bcell lymphoma [174]. These miRNAs regulate important processes including cell cycle, proliferation and apoptosis, and are overexpressed in lymphoma, leukemia and diverse solid cancers [175]. hnRNP A1 facilitates miR-18a microprocessing by binding to the stemloop sequence of $m i R-18 a$, which leads to the partial unwinding of its hairpin, thereby facilitating access to the microprocessor complex (Figure 2C) [176]. Knockdown of $h n R N P$ $A 1$ selectively impairs the expression of $m i R-18 a$ without changing the expression of the other five miRNA in the miR-17-92 cluster [172], demonstrating the specificity of this layer of microprocessor regulation.

The KH-type splicing regulatory protein (KSRP) primarily degrades mRNA by binding to AU-rich elements in their $3^{\prime}$-UTR [177], but it can also facilitate exon inclusion by binding to nearby intronic splice enhancers [178]. Interestingly, KSRP also enhances miRNA processing by binding GGG-triplets in miRNA stem-loop sequences [179]. Additionally, this interaction may be competitive with that of hnRNP A1. In the case of miRNA let-7a, hnRNP A1 binding displaced that of KSRP, thereby inhibiting the microprocessing of let-7a (Figure 2D) [180].

\subsection{Role of RNA $m^{6} A$ Modification}

The N6-methyladenine modification of RNA $\left(\mathrm{m}^{6} \mathrm{~A}\right)$, where the amine at the 6th carbon position of adenine is methylated, is the most common RNA epigenetic modification. Recent studies have shown that $\mathrm{m}^{6} \mathrm{~A}$ is required for the recruitment of DROSHA and other splicing factors that modulate microprocessing [181,182]. Co-transcriptionally, RNA 
polymerase II (Pol II) directly recruits DGCR8 to the nascent transcript, which in turn recruits DROSHA. This process depends on Cyclin Dependent Kinase 9 mediated phosphorylation of the C-terminal domain of Pol II [183]. DGCR8 recruitment to miRNA hairpins is facilitated by $\mathrm{m}^{6} \mathrm{~A}$ modification of GGAC residues in pri-miRNAs [181]. Consistent with this, knockdown of the gene encoding the $\mathrm{m}^{6} \mathrm{~A}$ writer Methyltransferase-like 3 led to reduction in the expression of many miRNAs [181].

Two hnRNPs, HNRNPA2B1 and HNRNPC, regulate microprocessing by binding to motifs that involve $\mathrm{m}^{6} \mathrm{~A}$ modifications. HNRNPA2B1 binds the RNA methylation mark $\mathrm{m}^{6} \mathrm{~A}$ in RGAC motifs at the basal junction of pri-miRNA hairpins [182]. This binding facilitates the recruitment of DGCR8 which in turn recruits DROSHA (Figure 2B) [182]. HNRNPC, known to bind to $\mathrm{m}^{6} \mathrm{~A}$ residues in GRACH motifs [184], was shown to facilitate $m i R-21$ processing [185]. miR-21 expression was dependent specifically on HNRNPC binding to its pri-miRNAs upstream of the hairpin. HNRNPC-regulated miR-21 expression targets the Programmed Cell Death 4 gene, thereby facilitating metastasis in glioblastoma [185]. Taken together, co-transcriptional RNA methylation facilitates microprocessing via the recruitment of DGCR8/DROSHA, HNRNPA2B1 and HNRNPC.

\subsection{The Microprocessor as a Splicing Factor}

Increasing evidence indicates that the microprocessor can regulate alternative splicing. Its splicing role was first characterized in the Eukaryotic Translation Initiation Factor $4 \mathrm{H}$ gene where DROSHA promotes skipping of its fifth exon [186], since this alternative exon forms a DROSHA substrate hairpin. Although DROSHA could cleave this exon as a microprocessor product, the effect of DROSHA on exon skipping is independent of its cleavage function, as dominant negative cleavage deficient DROSHA could also promote exon skipping [186].

In fact, DROSHA itself is a substrate of DROSHA-mediated exon skipping [187]. The $5^{\prime}$-splice site demarcating the seventh exon from its downstream intron forms a DROSHA substrate hairpin. DROSHA binding promotes the skipping of this exon [187]. Interestingly, skipping of exon 7 promotes nuclear localization of DROSHA whereas exon inclusion promotes cytoplasmic localization $[187,188]$. Although canonical miRNA processing occurs in the nucleus, emerging evidence indicates DROSHA can also process miRNAs in the cytoplasm [189]. Alternative splicing of DROSHA can also downregulate its activity by generating a unstable truncated DROSHA isoform (exon 27a inclusion) or a cleavageimpaired isoform (exon 32a inclusion) [190]. The enhanced expression of these novel DROSHA isoforms in various cancer datasets suggest that alternative splicing is actively exploited to downregulate microprocessing in cancer [190].

\subsection{Alternative Splicing and miRNA Biogenesis}

Alternative splicing and processing of intronic and other intragenic miRNAs can interact in myriad cooperative or competitive mechanisms. Splice site overlapping miRNAs (SO-miRNAs) exemplify the competitive relationship that miRNA processing can have with alternative splicing [191,192]. The inclusion of the alternate exon across which SOmiRNAs overlap results in removal of the intronic portion of its pri-miRNA sequence, thereby inhibiting its processing (Figure 2E). Conversely, microprocessing of SO-miRNAs lead to removal of the splice site, thereby inhibiting exon inclusion. We discussed earlier the role of SRSF1 in regulating the exon inclusion harboring SO-miRNA miR-222, thereby inhibiting miR-222 expression [168]. Another example is the tumor suppressor $m i R-34 b$ which resides on the acceptor splice site of the sole intron of its host gene. Minigene studies showed that intron splicing competitively inhibits the generation of miR-34b [191].

Melamed et al. detailed several characteristics peculiar to SO-miRNAs [192]. Firstly, SO-miRNA expression is typically lower than that of exonic or intronic miRNAs. This is exemplified by the example of murine $m i R-412$, which resides on a $3^{\prime}$-splice site of its host gene Mirg. Mirg also contains 9 additional miRNAs residing either on introns or exons. miR-412 was expressed at substantially lower levels than its neighboring intronic 
$m i R-541$ or exonic $m i R-410$ [192]. Moreover, $m i R-412$ expression was inversely proportional to the strength of its overlapping splice site [192], suggesting splice site recognition is in competition with microprocessor binding to SO-miRNA hairpins. Supporting this, DROSHA expression was inversely proportional to inclusion of the exon harboring the SO-miRNA miR-412 [192]. Moreover, $m i R-412$ expression was inversely proportional to the inclusion ratio of its overlapping exon [192]. This allowed $m i R-412$ to be differentially expressed in different tissues, in contrast to the other intronic or exonic miRNAs on the same host gene [192].

The competitive relationship between splicing and microprocessing may be a contextdependent phenomenon. For example, the DROSHA microprocessing of SO-miRNA had no general effect on exon inclusion levels in host genes [193]. To explain this discrepancy with earlier reports, the authors of this study proposed that after SO-miRNA processing, the remaining transcript often does not produce a spliced product, but instead leads to premature transcript termination [193].

Alternative splicing can also uncouple the expression of intronic miRNAs from their host genes (Figure 2F). For example, the Myosin Heavy Chain 7B (MYH7B) gene harbors $m i R-499$ on its 19 th intron. Skipping of the 7th exon in $M Y H 7 B$ causes a frameshift and introduces a premature termination codon in its 9 th exon. In this way, exon skipping destines the transcript for cytoplasmic nonsense-mediated decay and consequent downregulation of MYH7B. This occurs without affecting miR-499 expression levels [194]. Intragenic miRNAs can also be decoupled from host gene expression via alternative polyadenylation. For example, miR-21, residing on the terminal exon of its host gene Vacuole Membrane Protein 1 , can be downregulated by the alternative use of a polyadenylation site proximal to the miR-21 locus [195].

Alternative splicing can also affect miRNA expression by altering the cellular localization of its host transcript (Figure 2G). A recently characterized example is mediated by the FMS-like tyrosine kinase 3-internal tandem duplication (FLT3-ITD) mutation in acute myeloid leukemia (AML), where the FLT3-ITD upregulates miR-155 expression via intron retention in its host gene [189]. FLT3-ITD is a well-characterized poor-prognostic mutation in AML [196], and miR-155 is a well-established oncomiR that also confers poor prognosis [197]. FLT3-ITD up-regulates miR-155 in AML via two coordinated mechanisms. Firstly, FLT3-ITD mediated SPRED1 phosphorylation led to the inhibition of Exportin-5, broadly blocking the export of canonical pre-miRNAs [189]. Secondly, FLT3-ITD increased phosphorylation of the splicing factor DDX3X, thereby impairing the intron splicing of the host gene of $m i R-155$. These intron-retaining transcripts were exported to the cytoplasm via an alternate pathway mediated by Nuclear RNA Export Factor 1 (NXF1), bypassing the Exportin-5 blockade. Subsequently, miR-155 pre-miRNAs were microprocessed by cytoplasmic DROSHA isoforms [189]. This complex mechanism selectively enhances the expression of oncogenic $m i R-155$ relative to the expression of other miRNAs.

Taken together, alternative splicing can affect intragenic miRNA processing in myriad ways, depending on their transcriptomic contexts.

\section{Intronic miRNAs-Host Gene Interactions and Their Roles in Cancer}

The most important functional effect of miRNAs residing within introns is the consequent coupling of miRNA expression with its host gene, allowing for either synergistic or antagonistic interactions within the miRNA-host gene pair [24]. Most host genes are expressed in a positively correlated relationship with that of their intronic miRNAs [24,198]. Gene ontology analysis of miRNA-host gene pairs showed that intronic miRNAs target biological processes more significantly related to the function of their host genes than could be expected by chance [24]. This is supported by the observation that intronic miRNAs with functional association with their host genes are more likely to be evolutionarily conserved [199]. A balanced number of intronic miRNAs have a synergistic or antagonistic relationship with their host genes [24]. Moreover, about 20\% of all intronic miRNAs are predicted to directly target their host genes [200]. By targeting host genes, intronic miRNA 
can reduce the expression noise of their host gene, by quenching expression when there is a low level of host gene promoter activity [201].

Approximately $60 \%$ of all miRNAs reside in introns [18]. Introns are thought to be favorable regions for new miRNAs to arise, as intronic nucleotide repeats provide fertile ground for miRNA hairpins to evolve and these can be expressed without the need to co-evolve an independent promoter [202]. Consistent with this, older intronic miRNAs are more likely to be transcribed by an independent promoter [36]. Additionally, miRNAs in older host genes are more broadly expressed than those emerging in younger host genes [203]. França et al. explained these observations by separately considering miRNA emergence and fixation [203]. MiRNA emergence within introns are favorable as they coopt host promoters, without the need to evolve their own promoter [203]. However, fixation of intronic miRNA depend on several factors. MiRNA fixation is favored if their host promoter provided a breadth of expression across tissues [203]. Alternatively, wider tissue expression could be induced by the evolution of an independent promoter [203]. Another factor is the functional utility that the miRNA-host gene interaction provides $[199,203]$.

The predilection of miRNA to reside in introns demonstrates the utility of its interaction with its host gene, and this relationship can be either exploited or impaired in cancer. Numerous interactions between intronic miRNA and their host genes have been comprehensively reviewed elsewhere $[23,198,204]$. Here, we describe 3 examples of the more recently identified cancer-associated miRNA-host gene pairs in the following section. Other functionally characterized miRNA-host gene pairs are listed in Table 2.

Table 2. Functionally associated miRNA/Host gene pairs in cancer.

\begin{tabular}{cccc}
\hline miRNA & Host Gene & Cancer & Functional Association \\
\hline$h s a-m i R-196 b$ & HOXA9 & $\begin{array}{c}\text { Mixed lineage } \\
\text { leukemia }\end{array}$ & $\begin{array}{c}\text { Complex: miR-196b directly targets its host gene HOXA9 (oncogene) but } \\
\text { also targets FAS (tumor suppressor) [205] }\end{array}$ \\
\hline$h s a-m i R-204$ & TRPM3 & $\begin{array}{c}\text { Renal } \\
\text { Clear cell) }\end{array}$ & $\begin{array}{c}\text { Antagonism: inhibits TRPM3-induced proliferation by directly targeting } \\
\text { TRPM3; also inhibits oncogenic autophagy by targeting LC3B [206] }\end{array}$ \\
\hline$h s a-m i R-326$ & ARBB1 & Medulloblastoma & $\begin{array}{c}\text { Synergism: inhibits E2F1-associated pro-survival function by directly } \\
\text { targeting E2F1 (miR-326) and E2F1 acetylation (ARBB1) [207] }\end{array}$ \\
\hline$h s a-m i R-342$ & EVL & $\begin{array}{c}\text { Lymphoid } \\
\text { leukemia }\end{array}$ & $\begin{array}{c}\text { Antagonism: miR-342/EVL balance determines myeloid (high miR-342) } \\
\text { or lymphoid (high EVL) differentiation. miR-342 antagonises } \\
\text { EVL-induced lymphoid proliferation [208] }\end{array}$ \\
\hline$h s a-m i R-675$ & H19 & Breast & $\begin{array}{c}\text { Synergism: both promote cell migration, invasiveness and stemness [209] } \\
1205 / 1207\end{array}$ \\
\hline PVT1 & Various & $\begin{array}{c}\text { Synergism: PVT1 sponges multiple miRNAs, thereby enhancing tumor } \\
\text { proliferation induced by miR-1204, miR-1205 and miR-1207 [210] }\end{array}$ \\
\hline$h s a-m i R-3189$ & GDF15 & Various & $\begin{array}{c}\text { Antagonism: mir-3189 promotes p53-independent apoptosis; GDF15 is } \\
\text { implicated in metastasis [211] }\end{array}$ \\
\hline$h s a-m i R-4728$ & ERBB2 & Breast & $\begin{array}{c}\text { Synergism: inhibits apoptosis thereby promoting therapy resistance to } \\
\text { HER2(ERBB2) inhibitors [212] }\end{array}$ \\
\hline
\end{tabular}

\section{1. mir-615-3p/HOXC5 Axis and Telomerase Regulation}

mir-615-3p, residing in the intron of the Homeobox C5 (HOXC5) gene, is co-expressed along with its host gene but can also be expressed from its own promoter [213]. It primarily acts as a tumor suppressor gene but can also be oncogenic in some contexts [214]. For example, mir-615-3p inhibits tumor proliferation and metastasis in non-small cell lung cancer by targeting IGF2 [215]. Conversely, mir-615-3p can promote proliferation and tumor cell migration and inhibit apoptosis in gastric cancer by targeting CELF2 [216]. Importantly, mir-615-3p expression in differentiated cells target the TERT gene thereby leading to silencing of its gene product hTert, the protein subunit of telomeres. HOXC3 also downregulates TERT expression by interfering with the interaction between the TERT promoter and its enhancer [217]. Thus, the mir-615-3p/HOXC5 axis represents a synergistic 
mechanism that regulates telomerase expression and thereby replicative potential in normal cells. Aberrant silencing of HOXC5, such as via MUC1-C/BMI2 mediated silencing of HOX genes in breast cancer, can thereby disrupt this pathway and promote malignant transformation [218].

\section{2. $\mathrm{miR}-374 \mathrm{~b} / \mathrm{miR}-545 / \mathrm{FTX}$}

Recently, a screen for co-expressed miRNA-host gene pairs in colon cancer identified FTX as an oncogenic host gene harboring several intronic miRNAs [18]. The two miRNAs residing in the first intron of FTX, miR-374b and miR-545, enhanced proliferation by targeting PTEN and RIG-I, respectively, thereby enhancing PI3K-Akt signaling [18]. Conversely, miR-421, residing in a downstream intron of FTX, had an anti-tumor effect by inhibiting the DROSHA-dependent processing of $m i R-374 b$ and $m i R-545$ [18]. Additionally, FTX also interacts with DHX9 to promote aberrant adenosine-to-inosine RNA editing in multiple cancer cell types $[18,219]$. Thus, FTX overexpression along with its intronic miRNAs $m i R-374 b$ and $m i R-545$ promote colon cancer via two different but synergistic oncogenic pathways.

\section{3. miR-944/TP63 Axis and p53 Maintenance}

The transcription factor p63, transcribed by the Tumor Protein 63 (TP63) gene, belongs to the p53 family of transcription factors along with p73 [220]. miR-944 resides within the 6th intron of the TP63 gene. p63 regulates cell type specification, differentiation, proliferation and apoptosis [220]. Alternate transcription start site usage in TP63 gives rise to the truncated isoform $\triangle \mathrm{NP} 63 \alpha$. This isoform is normally expressed in highly proliferating squamous cells but is also a potent oncogene in squamous cell cancer [221]. Upregulation of $\triangle \mathrm{NP} 63 \alpha$ is associated with cisplatin resistance, which occurs in part due to aberrant alternative splicing of apoptosis factors [222]. Additionally, $\Delta \mathrm{NP} 63 \alpha$, in contrast to full-length p63, is a potent modulator of miRNA transcription and alters expression of multiple miRNAs including miR-944 promoter-driven expression [223]. In colon cancer, miR-944 stabilizes p53 by targeting the E3 ligases COP1 and MDM2 [224]. Thus, miR-944 acts as a tumor suppressor intronic miRNA by antagonizing its host transcript $\triangle \mathrm{NP} 63 \alpha$ in squamous cell cancers.

\section{Conclusions}

Splicing and intronic miRNA biogenesis are intertwined processes and their coregulation is currently underappreciated in cancer research. Introns are favorable locations for miRNA emergence and conservation through their ability to couple miRNA expression with functionally relevant host genes. Moreover, the myriad ways in which splicing factors can alter intronic miRNA expression adds yet another layer of complexity to gene expression regulation by miRNAs. These intricate networks of molecular relationships are either exploited or decoupled in cancer. Further characterization of intronic miRNAs with respect to alternative splicing and other RNA processing mechanisms is key to understanding how miRNAs are dysregulated in cancer and the development of new cancer therapies.

Author Contributions: This work was conceived by A.C.H.W. and J.E.J.R. The original draft preparation and writing: A.C.H.W. Review and editing: A.C.H.W. and J.E.J.R. Both authors have read and agreed to the published version of the manuscript.

Funding: This work was supported by the National Health and Medical Research Council (Project grants \#1128175 and \#1129901, and Investigator grant \#1177305 to J.E.J.R).

Institutional Review Board Statement: Not applicable.

Informed Consent Statement: Not applicable.

Data Availability Statement: Not applicable.

Conflicts of Interest: The authors declare no conflict of interest. 


\section{References}

1. Lee, R.C.; Feinbaum, R.L.; Ambros, V. The C. elegans heterochronic gene lin-4 encodes small RNAs with antisense complementarity to lin-14. Cell 1993, 75, 843-854. [CrossRef]

2. Berezikov, E. Evolution of microRNA diversity and regulation in animals. Nat. Rev. Genet. 2011, 12, 846-860. [CrossRef] [PubMed]

3. O'Brien, J.; Hayder, H.; Zayed, Y.; Peng, C. Overview of MicroRNA biogenesis, mechanisms of actions, and circulation. Front. Endocrinol. 2018, 9, 402. [CrossRef] [PubMed]

4. Förstemann, K.; Horwich, M.D.; Wee, L.; Tomari, Y.; Zamore, P.D. Drosophila microRNAs are sorted into functionally distinct argonaute complexes after production by Dicer-1. Cell 2007, 130, 287-297. [CrossRef]

5. Selbach, M.; Schwanhäusser, B.; Thierfelder, N.; Fang, Z.; Khanin, R.; Rajewsky, N. Widespread changes in protein synthesis induced by microRNAs. Nature 2008, 455, 58-63. [CrossRef]

6. Linsen, S.E.; Tops, B.B.; Cuppen, E. miRNAs: Small changes, widespread effects. Cell Res. 2008, 18, 1157-1159. [CrossRef] [PubMed]

7. Peng, Y.; Croce, C.M. The role of MicroRNAs in human cancer. Signal Transduct. Target. Ther. 2016, 1, 15004. [CrossRef]

8. Oliveto, S.; Mancino, M.; Manfrini, N.; Biffo, S. Role of microRNAs in translation regulation and cancer. World J. Biol. Chem. 2017, 8, 45-56. [CrossRef]

9. Si, W.; Shen, J.; Zheng, H.; Fan, W. The role and mechanisms of action of microRNAs in cancer drug resistance. Clin. Epigenetics 2019, 11, 25. [CrossRef]

10. Wong, G.K.; Passey, D.A.; Huang, Y.; Yang, Z.; Yu, J. Is “junk” DNA mostly intron DNA? Genome Res. 2000, 10, 1672-1678. [CrossRef]

11. Hubé, F.; Francastel, C. Mammalian introns: When the junk generates molecular diversity. Int. J. Mol. Sci. 2015, 16, 4429-4452. [CrossRef] [PubMed]

12. Schmitz, U.; Pinello, N.; Jia, F.; Alasmari, S.; Ritchie, W.; Keightley, M.C.; Shini, S.; Lieschke, G.J.; Wong, J.J.; Rasko, J.E.J. Intron retention enhances gene regulatory complexity in vertebrates. Genome Biol. 2017, 18, 216. [CrossRef] [PubMed]

13. Shaul, O. How introns enhance gene expression. Int. J. Biochem. Cell Biol. 2017, 91, 145-155. [CrossRef] [PubMed]

14. Wang, E.T.; Sandberg, R.; Luo, S.; Khrebtukova, I.; Zhang, L.; Mayr, C.; Kingsmore, S.F.; Schroth, G.P.; Burge, C.B. Alternative isoform regulation in human tissue transcriptomes. Nature 2008, 456, 470-476. [CrossRef]

15. Wong, J.J.; Au, A.Y.; Ritchie, W.; Rasko, J.E. Intron retention in mRNA: No longer nonsense: Known and putative roles of intron retention in normal and disease biology. Bioessays 2016, 38, 41-49. [CrossRef]

16. Boutz, P.L.; Bhutkar, A.; Sharp, P.A. Detained introns are a novel, widespread class of post-transcriptionally spliced introns. Genes Dev. 2015, 29, 63-80. [CrossRef]

17. Rearick, D.; Prakash, A.; McSweeny, A.; Shepard, S.S.; Fedorova, L.; Fedorov, A. Critical association of ncRNA with introns. Nucleic Acids Res. 2011, 39, 2357-2366. [CrossRef]

18. Kwok, Z.H.; Zhang, B.; Chew, X.H.; Chan, J.J.; Teh, V.; Yang, H.; Kappei, D.; Tay, Y. Systematic analysis of intronic miRNAs reveals cooperativity within the multicomponent FTX locus to promote colon cancer development. Cancer Res. 2021, 81, 1308-1320. [CrossRef]

19. Jo, B.S.; Choi, S.S. Introns: The functional benefits of introns in genomes. Genom. Inf. 2015, 13, 112-118. [CrossRef] [PubMed]

20. Baskerville, S.; Bartel, D.P. Microarray profiling of microRNAs reveals frequent coexpression with neighboring miRNAs and host genes. RNA 2005, 11, 241-247. [CrossRef]

21. Kim, Y.K.; Kim, V.N. Processing of intronic microRNAs. EMBO J. 2007, 26, 775-783. [CrossRef]

22. Morlando, M.; Ballarino, M.; Gromak, N.; Pagano, F.; Bozzoni, I.; Proudfoot, N.J. Primary microRNA transcripts are processed co-transcriptionally. Nat. Struct. Mol. Biol. 2008, 15, 902-909. [CrossRef]

23. Gao, X.; Qiao, Y.; Han, D.; Zhang, Y.; Ma, N. Enemy or partner: Relationship between intronic micrornas and their host genes. IUBMB Life 2012, 64, 835-840. [CrossRef] [PubMed]

24. Lutter, D.; Marr, C.; Krumsiek, J.; Lang, E.W.; Theis, F.J. Intronic microRNAs support their host genes by mediating synergistic and antagonistic regulatory effects. BMC Genom. 2010, 11, 224. [CrossRef]

25. Shomron, N.; Levy, C. MicroRNA-biogenesis and pre-mRNA splicing crosstalk. J. Biomed. Biotechnol. 2009, $2009,594678$. [CrossRef]

26. Faller, M.; Guo, F. MicroRNA biogenesis: There's more than one way to skin a cat. Biochim. Biophys. Acta 2008, $1779,663-667$. [CrossRef]

27. Monteys, A.M.; Spengler, R.M.; Wan, J.; Tecedor, L.; Lennox, K.A.; Xing, Y.; Davidson, B.L. Structure and activity of putative intronic miRNA promoters. RNA 2010, 16, 495-505. [CrossRef]

28. Roden, C.; Gaillard, J.; Kanoria, S.; Rennie, W.; Barish, S.; Cheng, J.; Pan, W.; Liu, J.; Cotsapas, C.; Ding, Y.; et al. Novel determinants of mammalian primary microRNA processing revealed by systematic evaluation of hairpin-containing transcripts and human genetic variation. Genome Res. 2017, 27, 374-384. [CrossRef]

29. Altuvia, Y.; Landgraf, P.; Lithwick, G.; Elefant, N.; Pfeffer, S.; Aravin, A.; Brownstein, M.J.; Tuschl, T.; Margalit, H. Clustering and conservation patterns of human microRNAs. Nucleic Acids Res. 2005, 33, 2697-2706. [CrossRef] [PubMed]

30. Han, J.; Lee, Y.; Yeom, K.H.; Nam, J.W.; Heo, I.; Rhee, J.K.; Sohn, S.Y.; Cho, Y.; Zhang, B.T.; Kim, V.N. Molecular basis for the recognition of primary microRNAs by the Drosha-DGCR8 complex. Cell 2006, 125, 887-901. [CrossRef] [PubMed] 
31. Okada, C.; Yamashita, E.; Lee, S.J.; Shibata, S.; Katahira, J.; Nakagawa, A.; Yoneda, Y.; Tsukihara, T. A high-resolution structure of the pre-microRNA nuclear export machinery. Science 2009, 326, 1275-1279. [CrossRef] [PubMed]

32. Yi, R.; Qin, Y.; Macara, I.G.; Cullen, B.R. Exportin-5 mediates the nuclear export of pre-microRNAs and short hairpin RNAs. Genes Dev. 2003, 17, 3011-3016. [CrossRef]

33. Zhang, X.; Zeng, Y. The terminal loop region controls microRNA processing by Drosha and Dicer. Nucleic Acids Res. 2010, 38, 7689-7697. [CrossRef] [PubMed]

34. Medley, J.C.; Panzade, G.; Zinovyeva, A.Y. microRNA strand selection: Unwinding the rules. Wiley Interdiscip. Rev. RNA 2021, 12, e1627. [CrossRef]

35. Lytle, J.R.; Yario, T.A.; Steitz, J.A. Target mRNAs are repressed as efficiently by microRNA-binding sites in the $5^{\prime}$ UTR as in the $3^{\prime}$ UTR. Proc. Natl. Acad. Sci. USA 2007, 104, 9667-9672. [CrossRef] [PubMed]

36. Marsico, A.; Huska, M.R.; Lasserre, J.; Hu, H.; Vucicevic, D.; Musahl, A.; Orom, U.; Vingron, M. PROmiRNA: A new miRNA promoter recognition method uncovers the complex regulation of intronic miRNAs. Genome Biol. 2013, 14, R84. [CrossRef] [PubMed]

37. Lin, S.L.; Miller, J.D.; Ying, S.Y. Intronic microRNA (miRNA). J. Biomed. Biotechnol. 2006, 2006, 26818. [CrossRef]

38. Kataoka, N.; Fujita, M.; Ohno, M. Functional association of the microprocessor complex with the spliceosome. Mol. Cell. Biol. 2009, 29, 3243-3254. [CrossRef] [PubMed]

39. Wen, J.; Ladewig, E.; Shenker, S.; Mohammed, J.; Lai, E.C. Analysis of nearly one thousand mammalian mirtrons reveals novel features of Dicer substrates. PLoS Comput. Biol. 2015, 11, e1004441. [CrossRef]

40. Ruby, J.G.; Jan, C.H.; Bartel, D.P. Intronic microRNA precursors that bypass Drosha processing. Nature 2007, 448, 83-86. [CrossRef] [PubMed]

41. Okamura, K.; Hagen, J.W.; Duan, H.; Tyler, D.M.; Lai, E.C. The mirtron pathway generates microRNA-class regulatory RNAs in Drosophila. Cell 2007, 130, 89-100. [CrossRef]

42. Berezikov, E.; Chung, W.J.; Willis, J.; Cuppen, E.; Lai, E.C. Mammalian mirtron genes. Mol. Cell 2007, 28, 328-336. [CrossRef] [PubMed]

43. Zeng, Y.; Cullen, B.R. Structural requirements for pre-microRNA binding and nuclear export by Exportin 5. Nucleic Acids Res. 2004, 32, 4776-4785. [CrossRef] [PubMed]

44. Westholm, J.O.; Lai, E.C. Mirtrons: microRNA biogenesis via splicing. Biochimie 2011, 93, 1897-1904. [CrossRef]

45. Flynt, A.S.; Greimann, J.C.; Chung, W.J.; Lima, C.D.; Lai, E.C. MicroRNA biogenesis via splicing and exosome-mediated trimming in Drosophila. Mol. Cell 2010, 38, 900-907. [CrossRef] [PubMed]

46. Liu, Q.; Greimann, J.C.; Lima, C.D. Reconstitution, activities, and structure of the eukaryotic RNA exosome. Cell 2006, 127, 1223-1237. [CrossRef]

47. Rorbach, G.; Unold, O.; Konopka, B.M. Distinguishing mirtrons from canonical miRNAs with data exploration and machine learning methods. Sci. Rep. 2018, 8, 7560. [CrossRef] [PubMed]

48. Lee, D.; Shin, C. Emerging roles of DROSHA beyond primary microRNA processing. RNA Biol. 2018, 15, 186-193. [CrossRef] [PubMed]

49. Gurtner, A.; Falcone, E.; Garibaldi, F.; Piaggio, G. Dysregulation of microRNA biogenesis in cancer: The impact of mutant p53 on Drosha complex activity. J. Exp. Clin. Cancer Res. 2016, 35, 45. [CrossRef]

50. Donayo, A.O.; Johnson, R.M.; Tseng, H.W.; Izreig, S.; Gariepy, A.; Mayya, V.K.; Wu, E.; Alam, R.; Lussier, C.; Jones, R.G.; et al. Oncogenic biogenesis of pri-miR-17 92 reveals hierarchy and competition among polycistronic MicroRNAs. Mol. Cell 2019, 75, 340-356. [CrossRef]

51. Mohammed, J.; Flynt, A.S.; Siepel, A.; Lai, E.C. The impact of age, biogenesis, and genomic clustering on Drosophila microRNA evolution. RNA 2013, 19, 1295-1308. [CrossRef] [PubMed]

52. Bai, X.; He, C.; Fu, B.; Kong, X.; Bu, J.; Zhu, K.; Zheng, W.; Zhou, F.; Ni, B. microRNA-877 contributes to decreased non-small cell lung cancer cell growth via the PI3K/AKT pathway by targeting tartrate resistant acid phosphatase 5 activity. Cell Cycle 2020, 19, 3260-3276. [CrossRef] [PubMed]

53. Zhu, H.; Wu, Y.; Kang, M.; Zhang, B. MiR-877 suppresses gastric cancer progression by downregulating AQP3. J. Int. Med. Res. 2020, 48, 300060520903661. [CrossRef] [PubMed]

54. Liang, J.; Zhang, S.; Wang, W.; Xu, Y.; Kawuli, A.; Lu, J.; Xiu, X. Long non-coding RNA DSCAM-AS1 contributes to the tumorigenesis of cervical cancer by targeting miR-877-5p/ATXN7L3 axis. Biosci. Rep. 2020, 40, BSR20192061. [CrossRef]

55. Du, L.J.; Mao, L.J.; Jing, R.J. Long noncoding RNA DNAH17-AS1 promotes tumorigenesis and metastasis of non-small cell lung cancer via regulating miR-877-5p/CCNA2 pathway. Biochem. Biophys. Res. Commun. 2020, 533, 565-572. [CrossRef]

56. Guo, T.; Wang, W.; Ji, Y.; Zhang, M.; Xu, G.; Lin, S. LncRNA PROX1-AS1 facilitates gastric cancer progression via miR-877-5p/PDL1 Axis. Cancer Manag. Res. 2021, 13, 2669-2680. [CrossRef]

57. Yan, T.H.; Qiu, C.; Sun, J.; Li, W.H. MiR-877-5p suppresses cell growth, migration and invasion by targeting cyclin dependent kinase 14 and predicts prognosis in hepatocellular carcinoma. Eur. Rev. Med. Pharmacol. Sci. 2018, 22, 3038-3046. [CrossRef]

58. Li, S.; Zhu, Y.; Liang, Z.; Wang, X.; Meng, S.; Xu, X.; Xu, X.; Wu, J.; Ji, A.; Hu, Z.; et al. Up-regulation of p16 by miR-877-3p inhibits proliferation of bladder cancer. Oncotarget 2016, 7, 51773-51783. [CrossRef]

59. Chen, S.; Li, K. HOXD-AS1 facilitates cell migration and invasion as an oncogenic lncRNA by competitively binding to miR-877-3p and upregulating FGF2 in human cervical cancer. BMC Cancer 2020, 20, 924. [CrossRef] [PubMed] 
60. Huang, X.; Qin, J.; Lu, S. Up-regulation of miR-877 induced by paclitaxel inhibits hepatocellular carcinoma cell proliferation though targeting FOXM1. Int. J. Clin. Exp. Pathol. 2015, 8, 1515-1524.

61. Wang, X.; Liu, L.; Zhao, W.; Li, Q.; Wang, G.; Li, H. LncRNA SNHG16 promotes the progression of laryngeal squamous cell carcinoma by mediating miR-877-5p/FOXP4 Axis. OncoTargets Ther. 2020, 13, 4569-4579. [CrossRef]

62. Zhou, G.; Xie, J.; Gao, Z.; Yao, W. MicroRNA-877 inhibits cell proliferation and invasion in non-small cell lung cancer by directly targeting IGF-1R. Exp. Ther. Med. 2019, 18, 1449-1457. [CrossRef]

63. Meng, F.; Ou, J.; Liu, J.; Li, X.; Meng, Y.; Yan, L.; Deng, P.; Sun, B. MicroRNA-877 is downregulated in cervical cancer and directly targets MACC1 to inhibit cell proliferation and invasion. Exp. Ther. Med. 2019, 18, 3650-3658. [CrossRef] [PubMed]

64. Zhang, L.; Li, C.; Cao, L.; Li, H.; Zou, H.; Li, H.; Pei, H. microRNA-877 inhibits malignant progression of colorectal cancer by directly targeting MTDH and regulating the PTEN/Akt pathway. Cancer Manag. Res. 2019, 11, 2769-2781. [CrossRef] [PubMed]

65. Yu, Y.; Bian, L.; Liu, R.; Wang, Y.; Xiao, X. Circular RNA hsa_circ_0061395 accelerates hepatocellular carcinoma progression via regulation of the miR-877-5p/PIK3R3 axis. Cancer Cell Int. 2021, 21, 10. [CrossRef]

66. Zhang, Y.; Zhu, H.; Sun, N.; Zhang, X.; Liang, G.; Zhu, J.; Xia, L.; Kou, Y.; Lu, J. Linc00941 regulates esophageal squamous cell carcinoma via functioning as a competing endogenous RNA for miR-877-3p to modulate PMEPA1 expression. Aging 2021, 13, 17830-17846. [CrossRef] [PubMed]

67. Xu, X.; Zheng, S. MiR-887-3p negatively regulates STARD13 and promotes pancreatic cancer progression. Cancer Manag. Res. 2020, 12, 6137-6147. [CrossRef] [PubMed]

68. Xie, H.; Shi, S.; Chen, Q.; Chen, Z. LncRNA TRG-AS1 promotes glioblastoma cell proliferation by competitively binding with miR-877-5p to regulate SUZ12 expression. Pathol. Res. Pract. 2019, 215, 152476. [CrossRef] [PubMed]

69. Xu, W.; Hu, G.Q.; Da Costa, C.; Tang, J.H.; Li, Q.R.; Du, L.; Pan, Y.W.; Lv, S.Q. Long noncoding RNA UBE2R2-AS1 promotes glioma cell apoptosis via targeting the miR-877-3p/TLR4 axis. OncoTargets Ther. 2019, 12, 3467-3480. [CrossRef] [PubMed]

70. Lu, J.; Wang, Y.H.; Yoon, C.; Huang, X.Y.; Xu, Y.; Xie, J.W.; Wang, J.B.; Lin, J.X.; Chen, Q.Y.; Cao, L.L.; et al. Circular RNA circ-RanGAP1 regulates VEGFA expression by targeting miR-877-3p to facilitate gastric cancer invasion and metastasis. Cancer Lett. 2020, 471, 38-48. [CrossRef]

71. Qian, J.; Li, R.; Wang, Y.Y.; Shi, Y.; Luan, W.K.; Tao, T.; Zhang, J.X.; Xu, Y.C.; You, Y.P. MiR-1224-5p acts as a tumor suppressor by targeting CREB1 in malignant gliomas. Mol. Cell. Biochem. 2015, 403, 33-41. [CrossRef] [PubMed]

72. Kong, L.; Liu, P.; Zheng, M.; Wang, Z.; Gao, Y.; Liang, K.; Wang, H.; Tan, X. The miR-1224-5p/ELF3 axis regulates malignant behaviors of pancreatic cancer via PI3K/AKT/Notch signaling pathways. OncoTargets Ther. 2020, 13, 3449-3466. [CrossRef] [PubMed]

73. Zuo, Y.; Shen, W.; Wang, C.; Niu, N.; Pu, J. Circular RNA circ-ZNF609 promotes lung adenocarcinoma proliferation by modulating miR-1224-3p/ETV1 signaling. Cancer Manag. Res. 2020, 12, 2471-2479. [CrossRef] [PubMed]

74. Wang, J.; Wen, T.; Li, Z.; Che, X.; Gong, L.; Yang, X.; Zhang, J.; Tang, H.; He, L.; Qu, X.; et al. MicroRNA-1224 inhibits tumor metastasis in intestinal-type gastric cancer by directly targeting FAK. Front. Oncol. 2019, 9, 222. [CrossRef]

75. Yu, P.F.; Wang, Y.; Lv, W.; Kou, D.; Hu, H.L.; Guo, S.S.; Zhao, Y.J. LncRNA NEAT1/miR-1224/KLF3 contributes to cell proliferation, apoptosis and invasion in lung cancer. Eur. Rev. Med. Pharmacol. Sci. 2019, 23, 8403-8410. [CrossRef]

76. Ran, F.; Zhang, Y.; Shi, Y.; Liu, J.; Li, H.; Ding, L.; Ye, Q. miR-1224-3p promotes breast cancer cell proliferation and migration through PGM5-mediated aerobic glycolysis. J. Oncol. 2021, 2021, 5529770. [CrossRef]

77. Jin, B.; Jin, D.; Zhuo, Z.; Zhang, B.; Chen, K. miR-1224-5p activates autophagy, cell invasion and inhibits epithelial-to-mesenchymal transition in osteosarcoma cells by directly targeting PLK1 through PI3K/AKT/mTOR signaling pathway. OncoTargets Ther. 2020, 13, 11807-11818. [CrossRef]

78. Yang, L.; Wang, M.; He, P. LncRNA NEAT1 promotes the progression of gastric cancer through modifying the miR-1224-5p/RSF1 signaling axis. Cancer Manag. Res. 2020, 12, 11845-11855. [CrossRef]

79. Song, N.S.; Pei, Z.D.; Fu, G. miR-1224-5p acts as a tumor suppressor via inhibiting the malignancy of rectal cancer through targeting SLC29A3. IUBMB Life 2020, 72, 2204-2213. [CrossRef]

80. Li, J.; Peng, W.; Yang, P.; Chen, R.; Gu, Q.; Qian, W.; Ji, D.; Wang, Q.; Zhang, Z.; Tang, J.; et al. microRNA-1224-5p inhibits metastasis and epithelial-mesenchymal transition in colorectal cancer by targeting SP1-mediated NF- $\mathrm{kB}$ signaling pathways. Front. Oncol. 2020, 10, 294. [CrossRef]

81. Wang, J.; Hu, Y.; Ye, C.; Liu, J. miR-1224-5p inhibits the proliferation and invasion of ovarian cancer via targeting SND1. Hum. Cell 2020, 33, 780-789. [CrossRef]

82. Chen, W.; Yu, Z.; Huang, W.; Yang, Y.; Wang, F.; Huang, H. LncRNA LINC00665 promotes prostate cancer progression via miR-1224-5p/SND1 axis. OncoTargets Ther. 2020, 13, 2527-2535. [CrossRef]

83. Xu, H.; Zhang, B.; Yang, Y.; Li, Z.; Zhao, P.; Wu, W.; Zhang, H.; Mao, J. LncRNA MIR4435-2HG potentiates the proliferation and invasion of glioblastoma cells via modulating miR-1224-5p/TGFBR2 axis. J. Cell. Mol. Med. 2020, 24, 6362-6372. [CrossRef]

84. Shi, Z.Z.; Wang, W.J.; Chen, Y.X.; Fan, Z.W.; Xie, X.F.; Yang, L.Y.; Chang, C.; Cai, Y.; Hao, J.J.; Wang, M.R.; et al. The miR1224-5p/TNS4/EGFR axis inhibits tumour progression in oesophageal squamous cell carcinoma. Cell Death Dis. 2020, $11,597$. [CrossRef] [PubMed]

85. Mohamadzade, Z.; Soltani, B.M.; Ghaemi, Z.; Hoseinpour, P. Cell specific tumor suppressor effect of hsa-miR-1226-3p through downregulation of HER2, PIK3R2, and AKT1 genes. Int. J. Biochem. Cell Biol. 2021, 134, 105965. [CrossRef] [PubMed] 
86. Park, E.J.; Jung, H.J.; Choi, H.J.; Jang, H.J.; Park, H.J.; Nejsum, L.N.; Kwon, T.H. Exosomes co-expressing AQP5-targeting miRNAs and IL-4 receptor-binding peptide inhibit the migration of human breast cancer cells. FASEB J. 2020, 34, 3379-3398. [CrossRef]

87. Chen, X.; Tan, W.; Li, W.; Li, W.; Zhu, S.; Zhong, J.; Shang, C.; Chen, Y. miR-1226-3p promotes sorafenib sensitivity of hepatocellular carcinoma via downregulation of DUSP4 expression. J. Cancer 2019, 10, 2745-2753. [CrossRef]

88. Liu, W.; Zhang, G.Q.; Zhu, D.Y.; Wang, L.J.; Li, G.T.; Xu, J.G.; Jin, X.L.; Zhu, Y.M.; Yang, X.Y. Long noncoding RNA ZFPM2-AS1 regulates ITGB1 by miR-1226-3p to promote cell proliferation and invasion in hepatocellular carcinoma. Eur. Rev. Med. Pharmacol. Sci. 2020, 24, 7612-7620. [CrossRef] [PubMed]

89. Jin, C.; Rajabi, H.; Kufe, D. miR-1226 targets expression of the mucin 1 oncoprotein and induces cell death. Int. J. Oncol. 2010, 37, 61-69. [CrossRef]

90. Jiang, X.; Chen, D. Circular RNA hsa_circ_0000658 inhibits osteosarcoma cell proliferation and migration via the miR-1227/IRF2 axis. J. Cell. Mol. Med. 2021, 25, 510-520. [CrossRef]

91. Liu, Y.; Chang, Y.; Cai, Y. circTNFRSF21, a newly identified circular RNA promotes endometrial carcinoma pathogenesis through regulating miR-1227-MAPK13/ATF2 axis. Aging 2020, 12, 6774-6792. [CrossRef]

92. Yang, L.; Wang, X.; Jiao, X.; Tian, B.; Zhang, M.; Zhou, C.; Wang, R.; Chen, H.; Wang, B.; Li, J.; et al. Suppressor of Ty 16 promotes lung cancer malignancy and is negatively regulated by miR-1227-5p. Cancer Sci. 2020, 111, 4075-4087. [CrossRef] [PubMed]

93. Jia, L.; Wu, J.; Zhang, L.; Chen, J.; Zhong, D.; Xu, S.; Xie, C.; Cai, J. Restoration of miR-1228* expression suppresses epithelialmesenchymal transition in gastric cancer. PLoS ONE 2013, 8, e58637. [CrossRef] [PubMed]

94. Jia, L.; Chen, J.; Xie, C.; Shao, L.; Xu, Z.; Zhang, L. microRNA-1228(*) impairs the pro-angiogenic activity of gastric cancer cells by targeting macrophage migration inhibitory factor. Life Sci. 2017, 180, 9-16. [CrossRef]

95. Chang, L.; Gao, H.; Wang, L.; Wang, N.; Zhang, S.; Zhou, X.; Yang, H. Exosomes derived from miR-1228 overexpressing bone marrow-mesenchymal stem cells promote growth of gastric cancer cells. Aging 2021, 13, 11808-11821. [CrossRef] [PubMed]

96. Lin, L.; Liu, D.; Liang, H.; Xue, L.; Su, C.; Liu, M. miR-1228 promotes breast cancer cell growth and metastasis through targeting SCAI protein. Int. J. Clin. Exp. Pathol. 2015, 8, 6646-6655. [PubMed]

97. Wang, J.W.; Wu, X.F.; Gu, X.J.; Jiang, X.H. Exosomal miR-1228 from cancer-associated fibroblasts promotes cell migration and invasion of osteosarcoma by directly targeting SCAI. Oncol. Res. 2019, 27, 979-986. [CrossRef]

98. Sun, J.; Li, X.; Yu, E.; Liu, J.; Sun, L.; He, Q.; Lu, Q. A novel tumor suppressor ASMTL-AS1 regulates the miR-1228-3p/SOX17/ $\beta-$ catenin axis in triple-negative breast cancer. Diagn. Pathol. 2021, 16, 45. [CrossRef]

99. Chen, D.; Ma, W.; Ke, Z.; Xie, F. CircRNA hsa_circ_100395 regulates miR-1228/TCF21 pathway to inhibit lung cancer progression. Cell Cycle 2018, 17, 2080-2090. [CrossRef]

100. Li, X.; Lin, S.; Mo, Z.; Jiang, J.; Tang, H.; Wu, C.; Song, J. CircRNA_100395 inhibits cell proliferation and metastasis in ovarian cancer via regulating miR-1228/p53/epithelial-mesenchymal transition (EMT) axis. J. Cancer 2020, 11, 599-609. [CrossRef]

101. Zhang, Y.; Dai, J.; Deng, H.; Wan, H.; Liu, M.; Wang, J.; Li, S.; Li, X.; Tang, H. miR-1228 promotes the proliferation and metastasis of hepatoma cells through a p53 forward feedback loop. Br. J. Cancer 2015, 112, 365-374. [CrossRef] [PubMed]

102. Tan, Z.; Zheng, H.; Liu, X.; Zhang, W.; Zhu, J.; Wu, G.; Cao, L.; Song, J.; Wu, S.; Song, L.; et al. MicroRNA-1229 overexpression promotes cell proliferation and tumorigenicity and activates $\mathrm{Wnt} / \beta$-catenin signaling in breast cancer. Oncotarget 2016, 7 , 24076-24087. [CrossRef] [PubMed]

103. Hu, H.Y.; Yu, C.H.; Zhang, H.H.; Zhang, S.Z.; Yu, W.Y.; Yang, Y.; Chen, Q. Exosomal miR-1229 derived from colorectal cancer cells promotes angiogenesis by targeting HIPK2. Int. J. Biol. Macromol. 2019, 132, 470-477. [CrossRef] [PubMed]

104. Zou, W.; Cao, Y.; Cheng, K.; Li, C.; Zhu, F.; Yang, S.; Jin, M.; Song, S. Downregulation of circ_0037655 impedes glioma formation and metastasis via the regulation of miR-1229-3p/ITGB8 axis. Open Life Sci. 2021, 16, 442-454. [CrossRef]

105. Cao, Q.; Shi, Y.; Wang, X.; Yang, J.; Mi, Y.; Zhai, G.; Zhang, M. Circular METRN RNA hsa_circ_0037251 promotes glioma progression by sponging miR-1229-3p and regulating mTOR expression. Sci. Rep. 2019, 9, 19791. [CrossRef] [PubMed]

106. Gao, R.; Cai, C.; Gan, J.; Yang, X.; Shuang, Z.; Liu, M.; Li, S.; Tang, H. miR-1236 down-regulates alpha-fetoprotein, thus causing PTEN accumulation, which inhibits the PI3K/Akt pathway and malignant phenotype in hepatoma cells. Oncotarget 2015, 6, 6014-6028. [CrossRef] [PubMed]

107. Wang, H.; Guo, M.; Ding, D.; Yang, F.; Chen, Z. Long non-coding RNA NNT-AS1 contributes to cisplatin resistance via miR-1236-3p/ATG7 axis in lung cancer cells. OncoTargets Ther. 2020, 13, 3641-3652. [CrossRef]

108. Hao, J.; Du, X.; Lv, F.; Shi, Q. Knockdown of circ_0006528 suppresses cell proliferation, migration, invasion, and adriamycin chemoresistance via regulating the miR-1236-3p/CHD4 axis in breast cancer. J. Surg. Res. 2021, 260, 104-115. [CrossRef]

109. Wang, C.; Tang, K.; Li, Z.; Chen, Z.; Xu, H.; Ye, Z. Targeted p21(WAF1/CIP1) activation by miR-1236 inhibits cell proliferation and correlates with favorable survival in renal cell carcinoma. Urol. Oncol. 2016, 34, 59.e23-34. [CrossRef]

110. Chen, S.Y.; Teng, S.C.; Cheng, T.H.; Wu, K.J. miR-1236 regulates hypoxia-induced epithelial-mesenchymal transition and cell migration/invasion through repressing SENP1 and HDAC3. Cancer Lett. 2016, 378, 59-67. [CrossRef]

111. Chen, L.; Chi, K.; Xiang, H.; Yang, Y. Circ_0032821 facilitates gastric cancer cell proliferation, migration, invasion and glycolysis by regulating MiR-1236-3p/HMGB1 axis. Cancer Manag. Res. 2020, 12, 9965-9976. [CrossRef]

112. Feng, W.; Gong, H.; Wang, Y.; Zhu, G.; Xue, T.; Wang, Y.; Cui, G. circIFT80 functions as a ceRNA of miR-1236-3p to promote colorectal cancer progression. Mol. Ther. Nucleic Acids 2019, 18, 375-387. [CrossRef]

113. Duan, X.; Liu, D.; Wang, Y.; Chen, Z. Circular RNA hsa_circ_0074362 promotes glioma cell proliferation, migration, and invasion by attenuating the inhibition of miR-1236-3p on HOXB7 expression. DNA Cell Biol. 2018, 37, 917-924. [CrossRef] [PubMed] 
114. Bian, T.; Jiang, D.; Liu, J.; Yuan, X.; Feng, J.; Li, Q.; Zhang, Q.; Li, X.; Liu, Y.; Zhang, J. miR-1236-3p suppresses the migration and invasion by targeting KLF8 in lung adenocarcinoma A549 cells. Biochem. Biophys. Res. Commun. 2017, 492, 461-467. [CrossRef] [PubMed]

115. An, J.X.; Ma, M.H.; Zhang, C.D.; Shao, S.; Zhou, N.M.; Dai, D.Q. miR-1236-3p inhibits invasion and metastasis in gastric cancer by targeting MTA2. Cancer Cell Int. 2018, 18, 66. [CrossRef] [PubMed]

116. Jia, Z.; Zhu, H.; Sun, H.; Hua, Y.; Zhang, G.; Jiang, J.; Wang, X. Adipose mesenchymal stem cell-derived exosomal microRNA-1236 reduces resistance of breast cancer cells to cisplatin by suppressing SLC9A1 and the Wnt/ $\beta$-catenin signaling. Cancer Manag. Res. 2020, 12, 8733-8744. [CrossRef] [PubMed]

117. Wang, Z.; Liu, L.; Guo, X.; Guo, C.; Wang, W. microRNA-1236-3p regulates DDP resistance in lung cancer cells. Open Med. 2018, 14, 41-51. [CrossRef] [PubMed]

118. Song, T.F.; Xu, A.L.; Chen, X.H.; Gao, J.Y.; Gao, F.; Kong, X.C. Circular RNA circRNA_101996 promoted cervical cancer development by regulating miR-1236-3p/TRIM37 axis. Kaohsiung J. Med. Sci. 2021, 37, 547-561. [CrossRef] [PubMed]

119. Wang, Y.; Yan, S.; Liu, X.; Zhang, W.; Li, Y.; Dong, R.; Zhang, Q.; Yang, Q.; Yuan, C.; Shen, K.; et al. miR-1236-3p represses the cell migration and invasion abilities by targeting ZEB1 in high-grade serous ovarian carcinoma. Oncol. Rep. 2014, 31, 1905-1910. [CrossRef]

120. Liang, T.C.; Fu, W.G.; Zhong, Y.S. MicroRNA-1236-3p inhibits proliferation and invasion of breast cancer cells by targeting ZEB1. Eur. Rev. Med. Pharmacol. Sci. 2019, 23, 9988-9995. [CrossRef]

121. Fang, H.; Jiang, W.; Jing, Z.; Mu, X.; Xiong, Z. miR-937 regulates the proliferation and apoptosis via targeting APAF1 in breast cancer. OncoTargets Ther. 2019, 12, 5687-5699. [CrossRef]

122. Li, D.; Zhong, J.; Zhang, G.; Lin, L.; Liu, Z. Oncogenic role and prognostic value of microRNA-937-3p in patients with breast cancer. OncoTargets Ther. 2019, 12, 11045-11056. [CrossRef] [PubMed]

123. Han, X.; Guo, X.; Zhang, W.; Cong, Q. MicroRNA-937 inhibits the malignant phenotypes of breast cancer by directly targeting and downregulating forkhead box Q1. OncoTargets Ther. 2019, 12, 4813-4824. [CrossRef] [PubMed]

124. Zhang, L.; Zeng, D.; Chen, Y.; Li, N.; Lv, Y.; Li, Y.; Xu, X.; Xu, G. miR-937 contributes to the lung cancer cell proliferation by targeting INPP4B. Life Sci. 2016, 155, 110-115. [CrossRef] [PubMed]

125. Xiong, X.; Xu, W.; Gong, J.; Wang, L.; Dai, M.; Chen, G.; Yuan, L. miR-937-5p targets SOX17 to modulate breast cancer cell cycle and cell proliferation through the Wnt signaling pathway. Cell. Signal. 2021, 77, 109818. [CrossRef]

126. Zeng, W.; Liu, Y.; Li, W.T.; Li, Y.; Zhu, J.F. CircFNDC3B sequestrates miR-937-5p to derepress TIMP3 and inhibit colorectal cancer progression. Mol. Oncol. 2020, 14, 2960-2984. [CrossRef] [PubMed]

127. Ying, X.; Li-ya, Q.; Feng, Z.; Yin, W.; Ji-hong, L. miR-939 promotes the proliferation of human ovarian cancer cells by repressing APC2 expression. Biomed. Pharmacother. 2015, 71, 64-69. [CrossRef]

128. Shen, Y.; Chen, G.; Gao, H.; Li, Y.; Zhuang, L.; Meng, Z.; Liu, L. miR-939-5p contributes to the migration and invasion of pancreatic cancer by targeting ARHGAP4. OncoTargets Ther. 2020, 13, 389-399. [CrossRef]

129. Cui, C.; Yu, J.; Huang, S.; Zhu, H.; Huang, Z. Transcriptional regulation of gene expression by microRNAs as endogenous decoys of transcription factors. Cell. Physiol. Biochem. 2014, 33, 1698-1714. [CrossRef]

130. Cui, C.; Zhai, D.; Cai, L.; Duan, Q.; Xie, L.; Yu, J. Long noncoding RNA HEIH promotes colorectal cancer tumorigenesis via counteracting miR-939-mediated transcriptional repression of Bcl-xL. Cancer Res. Treat. 2018, 50, 992-1008. [CrossRef]

131. Di Modica, M.; Regondi, V.; Sandri, M.; Iorio, M.V.; Zanetti, A.; Tagliabue, E.; Casalini, P.; Triulzi, T. Breast cancer-secreted miR-939 downregulates VE-cadherin and destroys the barrier function of endothelial monolayers. Cancer Lett. 2017, 384, 94-100. [CrossRef] [PubMed]

132. Situ, J.; Zhang, H.; Jin, Z.; Li, K.; Mao, Y.; Huang, W. MicroRNA-939 directly targets HDGF to inhibit the aggressiveness of prostate cancer via deactivation of the WNT/ $\beta$-catenin pathway. OncoTargets Ther. 2020, 13, 4257-4270. [CrossRef] [PubMed]

133. Zhao, X.; Li, J.; Yu, D. MicroRNA-939-5p directly targets IGF-1R to inhibit the aggressive phenotypes of osteosarcoma through deactivating the PI3K/Akt pathway. Int. J. Mol. Med. 2019, 44, 1833-1843. [CrossRef] [PubMed]

134. Garbin, A.; Lovisa, F.; Holmes, A.B.; Damanti, C.C.; Gallingani, I.; Carraro, E.; Accordi, B.; Veltri, G.; Pizzi, M.; d’Amore, E.S.G.; et al. miR-939 acts as tumor suppressor by modulating JUNB transcriptional activity in pediatric anaplastic large cell lymphoma. Haematologica 2021, 106, 610-613. [CrossRef]

135. Zhang, Y.; Liu, X.; Li, Q.; Zhang, Y. lncRNA LINC00460 promoted colorectal cancer cells metastasis via miR-939-5p sponging. Cancer Manag. Res. 2019, 11, 1779-1789. [CrossRef]

136. Aghdaei, F.H.; Soltani, B.M.; Dokanehiifard, S.; Mowla, S.J.; Soleimani, M. Overexpression of hsa-miR-939 follows by NGFR down-regulation and apoptosis reduction. J. Biosci. 2017, 42, 23-30. [CrossRef]

137. Zhang, J.X.; Xu, Y.; Gao, Y.; Chen, C.; Zheng, Z.S.; Yun, M.; Weng, H.W.; Xie, D.; Ye, S. Decreased expression of miR-939 contributes to chemoresistance and metastasis of gastric cancer via dysregulation of SLC34A2 and Raf/MEK/ERK pathway. Mol. Cancer 2017, 16, 18. [CrossRef] [PubMed]

138. Chen, A.; Liu, S.; Lu, X.; Wei, L.; Chen, Y. Inhibition of microRNA-939 suppresses the development of human non-small cell lung cancer via the upregulation of tissue inhibitor of metalloproteinases 2. Mol. Med. Rep. 2018, 18, 4831-4838. [CrossRef]

139. Hui, W.; Ma, X.; Zan, Y.; Song, L.; Zhang, S.; Dong, L. MicroRNA-1292-5p inhibits cell growth, migration and invasion of gastric carcinoma by targeting DEK. Am. J. Cancer Res. 2018, 8, 1228-1238. 
140. Wang, J.; Li, M.; Han, X.; Wang, H.; Wang, X.; Ma, G.; Xia, T.; Wang, S. miR-1976 knockdown promotes epithelial-mesenchymal transition and cancer stem cell properties inducing triple-negative breast cancer metastasis. Cell Death Dis. 2020, 11, 500. [CrossRef]

141. Chen, G.; Hu, J.; Huang, Z.; Yang, L.; Chen, M. MicroRNA-1976 functions as a tumor suppressor and serves as a prognostic indicator in non-small cell lung cancer by directly targeting PLCE1. Biochem. Biophys. Res. Commun. 2016, 473, 1144-1151. [CrossRef] [PubMed]

142. Pekow, J.; Hutchison, A.L.; Meckel, K.; Harrington, K.; Deng, Z.; Talasila, N.; Rubin, D.T.; Hanauer, S.B.; Hurst, R.; Umanskiy, K.; et al. miR-4728-3p functions as a tumor suppressor in ulcerative colitis-associated colorectal neoplasia through regulation of focal adhesion signaling. Inflamm. Bowel Dis. 2017, 23, 1328-1337. [CrossRef] [PubMed]

143. Zhou, Y.; Yuan, Y.; Li, L.; Wang, X.; Quan, Y.; Liu, C.; Yu, M.; Hu, X.; Meng, X.; Zhou, Z.; et al. HER2-intronic miR-4728-5p facilitates HER2 expression and accelerates cell proliferation and migration by targeting EBP1 in breast cancer. PLoS ONE 2021, 16, e0245832. [CrossRef]

144. Newie, I.; Søkilde, R.; Persson, H.; Grabau, D.; Rego, N.; Kvist, A.; von Stedingk, K.; Axelson, H.; Borg, Å.; VallonChristersson, J.; et al. The HER2-encoded miR-4728-3p regulates ESR1 through a non-canonical internal seed interaction. PLoS ONE 2014, 9, e97200. [CrossRef]

145. Schmitt, D.C.; Madeira da Silva, L.; Zhang, W.; Liu, Z.; Arora, R.; Lim, S.; Schuler, A.M.; McClellan, S.; Andrews, J.F.; Kahn, A.G.; et al. ErbB2-intronic microRNA-4728: A novel tumor suppressor and antagonist of oncogenic MAPK signaling. Cell Death Dis. 2015, 6, e1742. [CrossRef] [PubMed]

146. Newie, I.; Søkilde, R.; Persson, H.; Jacomasso, T.; Gorbatenko, A.; Borg, Å.; de Hoon, M.; Pedersen, S.F.; Rovira, C. HER2-encoded mir-4728 forms a receptor-independent circuit with miR-21-5p through the non-canonical poly(A) polymerase PAPD5. Sci. Rep. 2016, 6, 35664. [CrossRef] [PubMed]

147. Hu, Y.; Zhang, X.; Gong, C.; Li, J. Aberrant expression of miR-4728 in patients with non-small cell lung cancer and its regulatory effects on tumor progression in tumor cells. Exp. Ther. Med. 2020, 20, 15. [CrossRef]

148. Zhou, W.; Ding, X.; Jin, P.; Li, P. miR-6838-5p affects cell growth, migration, and invasion by targeting GPRIN3 via the Wnt/ $\beta$ catenin signaling pathway in gastric cancer. Pathobiology 2020, 87, 327-337. [CrossRef]

149. Liu, G.; Wang, P.; Zhang, H. miR-6838-5p suppresses cell metastasis and the EMT process in triple-negative breast cancer by targeting WNT3A to inhibit the WNT pathway. J. Gene Med. 2019, 21, e3129. [CrossRef]

150. Yu, H.; Zhang, J.; Wen, Q.; Dai, Y.; Zhang, W.; Li, F.; Li, J. MicroRNA-6852 suppresses cell proliferation and invasion via targeting forkhead box J1 in gastric cancer. Exp. Ther. Med. 2018, 16, 3249-3255. [CrossRef]

151. Wang, J.; Liu, H.; Zheng, K.; Zhang, S.; Dong, W. MicroRNA-6852 suppresses glioma A172 cell proliferation and invasion by targeting LEF1. Exp. Ther. Med. 2019, 18, 1877-1883. [CrossRef]

152. Shi, M.; Li, Z.Y.; Zhang, L.M.; Wu, X.Y.; Xiang, S.H.; Wang, Y.G.; Zhang, Y.Q. Hsa_circ_0007456 regulates the natural killer cell-mediated cytotoxicity toward hepatocellular carcinoma via the miR-6852-3p/ICAM-1 axis. Cell Death Dis. 2021, 12, 94. [CrossRef]

153. Cui, B.H.; Hong, X. miR-6852 serves as a prognostic biomarker in colorectal cancer and inhibits tumor growth and metastasis by targeting TCF7. Exp. Ther. Med. 2018, 16, 879-885. [CrossRef] [PubMed]

154. Wahl, M.C.; Will, C.L.; Lührmann, R. The spliceosome: Design principles of a dynamic RNP machine. Cell 2009, 136, 701-718. [CrossRef] [PubMed]

155. Reed, R. Initial splice-site recognition and pairing during pre-mRNA splicing. Curr. Opin. Genet. Dev. 1996, 6, 215-220. [CrossRef]

156. Fu, X.D.; Ares, M., Jr. Context-dependent control of alternative splicing by RNA-binding proteins. Nat. Rev. Genet. 2014, 15, 689-701. [CrossRef] [PubMed]

157. Agranat-Tamir, L.; Shomron, N.; Sperling, J.; Sperling, R. Interplay between pre-mRNA splicing and microRNA biogenesis within the supraspliceosome. Nucleic Acids Res. 2014, 42, 4640-4651. [CrossRef] [PubMed]

158. Ip, J.Y.; Schmidt, D.; Pan, Q.; Ramani, A.K.; Fraser, A.G.; Odom, D.T.; Blencowe, B.J. Global impact of RNA polymerase II elongation inhibition on alternative splicing regulation. Genome Res. 2011, 21, 390-401. [CrossRef]

159. Pawlicki, J.M.; Steitz, J.A. Primary microRNA transcript retention at sites of transcription leads to enhanced microRNA production. J. Cell Biol. 2008, 182, 61-76. [CrossRef] [PubMed]

160. Glaich, O.; Parikh, S.; Bell, R.E.; Mekahel, K.; Donyo, M.; Leader, Y.; Shayevitch, R.; Sheinboim, D.; Yannai, S.; Hollander, D.; et al. DNA methylation directs microRNA biogenesis in mammalian cells. Nat. Commun. 2019, 10, 5657. [CrossRef] [PubMed]

161. Cheng, T.L.; Wang, Z.; Liao, Q.; Zhu, Y.; Zhou, W.H.; Xu, W.; Qiu, Z. MeCP2 suppresses nuclear microRNA processing and dendritic growth by regulating the DGCR8/Drosha complex. Dev. Cell 2014, 28, 547-560. [CrossRef] [PubMed]

162. Shayevitch, R.; Askayo, D.; Keydar, I.; Ast, G. The importance of DNA methylation of exons on alternative splicing. RNA 2018, 24, 1351-1362. [CrossRef] [PubMed]

163. Wong, J.J.; Gao, D.; Nguyen, T.V.; Kwok, C.T.; van Geldermalsen, M.; Middleton, R.; Pinello, N.; Thoeng, A.; Nagarajah, R.; Holst, J.; et al. Intron retention is regulated by altered MeCP2-mediated splicing factor recruitment. Nat. Commun. 2017, 8, 15134. [CrossRef] [PubMed]

164. Schor, I.E.; Gómez Acuña, L.I.; Kornblihtt, A.R. Coupling between transcription and alternative splicing. Cancer Treat. Res. 2013, 158, 1-24. [CrossRef] [PubMed] 
165. Janas, M.M.; Khaled, M.; Schubert, S.; Bernstein, J.G.; Golan, D.; Veguilla, R.A.; Fisher, D.E.; Shomron, N.; Levy, C.; Novina, C.D. Feed-forward microprocessing and splicing activities at a microRNA-containing intron. PLoS Genet. 2011, 7, e1002330. [CrossRef]

166. Adams, D.J.; van der Weyden, L.; Mayeda, A.; Stamm, S.; Morris, B.J.; Rasko, J.E. ZNF265-a novel spliceosomal protein able to induce alternative splicing. J. Cell Biol. 2001, 154, 25-32. [CrossRef]

167. Wu, H.; Sun, S.; Tu, K.; Gao, Y.; Xie, B.; Krainer, A.R.; Zhu, J. A splicing-independent function of SF2/ASF in microRNA processing. Mol. Cell 2010, 38, 67-77. [CrossRef]

168. Sun, Q.; Hao, Q.; Lin, Y.C.; Song, Y.J.; Bangru, S.; Arif, W.; Tripathi, V.; Zhang, Y.; Cho, J.H.; Freier, S.M.; et al. Antagonism between splicing and microprocessor complex dictates the serum-induced processing of lnc-MIRHG for efficient cell cycle reentry. RNA 2020, 26, 1603-1620. [CrossRef]

169. Butkytè, S.; Čiupas, L.; Jakubauskienè, E.; Vilys, L.; Mocevicius, P.; Kanopka, A.; Vilkaitis, G. Splicing-dependent expression of microRNAs of mirtron origin in human digestive and excretory system cancer cells. Clin. Epigenetics 2016, 8, 33. [CrossRef]

170. Kim, K.; Nguyen, T.D.; Li, S.; Nguyen, T.A. SRSF3 recruits DROSHA to the basal junction of primary microRNAs. RNA 2018, 24, 892-898. [CrossRef]

171. Ajiro, M.; Jia, R.; Yang, Y.; Zhu, J.; Zheng, Z.M. A genome landscape of SRSF3-regulated splicing events and gene expression in human osteosarcoma U2OS cells. Nucleic Acids Res. 2016, 44, 1854-1870. [CrossRef]

172. Guil, S.; Cáceres, J.F. The multifunctional RNA-binding protein hnRNP A1 is required for processing of miR-18a. Nat. Struct. Mol. Biol. 2007, 14, 591-596. [CrossRef]

173. He, L.; Thomson, J.M.; Hemann, M.T.; Hernando-Monge, E.; Mu, D.; Goodson, S.; Powers, S.; Cordon-Cardo, C.; Lowe, S.W.; Hannon, G.J.; et al. A microRNA polycistron as a potential human oncogene. Nature 2005, 435, 828-833. [CrossRef] [PubMed]

174. Ota, A.; Tagawa, H.; Karnan, S.; Tsuzuki, S.; Karpas, A.; Kira, S.; Yoshida, Y.; Seto, M. Identification and characterization of a novel gene, C13orf25, as a target for 13q31-q32 amplification in malignant lymphoma. Cancer Res. 2004, 64, 3087-3095. [CrossRef] [PubMed]

175. Mogilyansky, E.; Rigoutsos, I. The miR-17/92 cluster: A comprehensive update on its genomics, genetics, functions and increasingly important and numerous roles in health and disease. Cell Death Differ. 2013, 20, 1603-1614. [CrossRef]

176. Kooshapur, H.; Choudhury, N.R.; Simon, B.; Mühlbauer, M.; Jussupow, A.; Fernandez, N.; Jones, A.N.; Dallmann, A.; Gabel, F.; Camilloni, C.; et al. Structural basis for terminal loop recognition and stimulation of pri-miRNA-18a processing by hnRNP A1. Nat. Commun. 2018, 9, 2479. [CrossRef]

177. Gherzi, R.; Lee, K.Y.; Briata, P.; Wegmüller, D.; Moroni, C.; Karin, M.; Chen, C.Y. A KH domain RNA binding protein, KSRP, promotes ARE-directed mRNA turnover by recruiting the degradation machinery. Mol. Cell 2004, 14, 571-583. [CrossRef]

178. Min, H.; Turck, C.W.; Nikolic, J.M.; Black, D.L. A new regulatory protein, KSRP, mediates exon inclusion through an intronic splicing enhancer. Genes Dev. 1997, 11, 1023-1036. [CrossRef]

179. Trabucchi, M.; Briata, P.; Garcia-Mayoral, M.; Haase, A.D.; Filipowicz, W.; Ramos, A.; Gherzi, R.; Rosenfeld, M.G. The RNAbinding protein KSRP promotes the biogenesis of a subset of microRNAs. Nature 2009, 459, 1010-1014. [CrossRef] [PubMed]

180. Michlewski, G.; Cáceres, J.F. Antagonistic role of hnRNP A1 and KSRP in the regulation of let-7a biogenesis. Nat. Struct. Mol. Biol. 2010, 17, 1011-1018. [CrossRef]

181. Alarcón, C.R.; Lee, H.; Goodarzi, H.; Halberg, N.; Tavazoie, S.F. N6-methyladenosine marks primary microRNAs for processing. Nature 2015, 519, 482-485. [CrossRef] [PubMed]

182. Alarcón, C.R.; Goodarzi, H.; Lee, H.; Liu, X.; Tavazoie, S.; Tavazoie, S.F. HNRNPA2B1 Is a mediator of m(6)A-dependent nuclear RNA processing events. Cell 2015, 162, 1299-1308. [CrossRef] [PubMed]

183. Church, V.A.; Pressman, S.; Isaji, M.; Truscott, M.; Cizmecioglu, N.T.; Buratowski, S.; Frolov, M.V.; Carthew, R.W. Microprocessor recruitment to elongating RNA polymerase II is required for differential expression of microRNAs. Cell Rep. 2017, 20, 3123-3134. [CrossRef]

184. Liu, N.; Dai, Q.; Zheng, G.; He, C.; Parisien, M.; Pan, T. N(6)-methyladenosine-dependent RNA structural switches regulate RNA-protein interactions. Nature 2015, 518, 560-564. [CrossRef]

185. Park, Y.M.; Hwang, S.J.; Masuda, K.; Choi, K.M.; Jeong, M.R.; Nam, D.H.; Gorospe, M.; Kim, H.H. Heterogeneous nuclear ribonucleoprotein $\mathrm{C} 1 / \mathrm{C} 2$ controls the metastatic potential of glioblastoma by regulating PDCD4. Mol. Cell. Biol. 2012, 32, 4237-4244. [CrossRef] [PubMed]

186. Havens, M.A.; Reich, A.A.; Hastings, M.L. Drosha promotes splicing of a pre-microRNA-like alternative exon. PLoS Genet. 2014, 10, e1004312. [CrossRef] [PubMed]

187. Lee, D.; Nam, J.W.; Shin, C. DROSHA targets its own transcript to modulate alternative splicing. RNA 2017, $23,1035-1047$. [CrossRef]

188. Link, S.; Grund, S.E.; Diederichs, S. Alternative splicing affects the subcellular localization of Drosha. Nucleic Acids Res. 2016, 44, 5330-5343. [CrossRef]

189. Nguyen, L.X.T.; Zhang, B.; Hoang, D.H.; Zhao, D.; Wang, H.; Wu, H.; Su, Y.L.; Dong, H.; Rodriguez-Rodriguez, S.; Armstrong, B.; et al. Cytoplasmic DROSHA and non-canonical mechanisms of MiR-155 biogenesis in FLT3-ITD acute myeloid leukemia. Leukemia 2021, 35, 2285-2298. [CrossRef]

190. Dai, L.; Hallmark, L.; Bofill De Ros, X.; Crouch, H.; Chen, S.; Shi, T.; Yang, A.; Lian, C.; Zhao, Y.; Tran, B.; et al. Novel, abundant Drosha isoforms are deficient in miRNA processing in cancer cells. RNA Biol. 2020, 17, 1603-1612. [CrossRef] 
191. Mattioli, C.; Pianigiani, G.; Pagani, F. A competitive regulatory mechanism discriminates between juxtaposed splice sites and pri-miRNA structures. Nucleic Acids Res. 2013, 41, 8680-8691. [CrossRef]

192. Melamed, Z.; Levy, A.; Ashwal-Fluss, R.; Lev-Maor, G.; Mekahel, K.; Atias, N.; Gilad, S.; Sharan, R.; Levy, C.; Kadener, S.; et al. Alternative splicing regulates biogenesis of miRNAs located across exon-intron junctions. Mol. Cell 2013, 50, 869-881. [CrossRef]

193. Pianigiani, G.; Licastro, D.; Fortugno, P.; Castiglia, D.; Petrovic, I.; Pagani, F. Microprocessor-dependent processing of splice site overlapping microRNA exons does not result in changes in alternative splicing. RNA 2018, 24, 1158-1171. [CrossRef]

194. Bell, M.L.; Buvoli, M.; Leinwand, L.A. Uncoupling of expression of an intronic microRNA and its myosin host gene by exon skipping. Mol. Cell. Biol. 2010, 30, 1937-1945. [CrossRef] [PubMed]

195. Ribas, J.; Ni, X.; Castanares, M.; Liu, M.M.; Esopi, D.; Yegnasubramanian, S.; Rodriguez, R.; Mendell, J.T.; Lupold, S.E. A novel source for miR-21 expression through the alternative polyadenylation of VMP1 gene transcripts. Nucleic Acids Res. 2012, 40, 6821-6833. [CrossRef]

196. Lagunas-Rangel, F.A.; Chávez-Valencia, V. FLT3-ITD and its current role in acute myeloid leukaemia. Med. Oncol. 2017, 34, 114. [CrossRef] [PubMed]

197. Narayan, N.; Bracken, C.P.; Ekert, P.G. MicroRNA-155 expression and function in AML: An evolving paradigm. Exp. Hematol. 2018, 62, 1-6. [CrossRef] [PubMed]

198. Liu, B.; Shyr, Y.; Cai, J.; Liu, Q. Interplay between miRNAs and host genes and their role in cancer. Brief. Funct. Genom. 2018, 18, 255-266. [CrossRef] [PubMed]

199. Steiman-Shimony, A.; Shtrikman, O.; Margalit, H. Assessing the functional association of intronic miRNAs with their host genes. RNA 2018, 24, 991-1004. [CrossRef]

200. Hinske, L.C.; Galante, P.A.; Kuo, W.P.; Ohno-Machado, L. A potential role for intragenic miRNAs on their hosts' interactome. BMC Genom. 2010, 11, 533. [CrossRef] [PubMed]

201. Kang, T.; Quarton, T.; Nowak, C.M.; Ehrhardt, K.; Singh, A.; Li, Y.; Bleris, L. Robust filtering and noise suppression in intragenic miRNA-mediated host regulation. iScience 2020, 23, 101595. [CrossRef]

202. Campo-Paysaa, F.; Sémon, M.; Cameron, R.A.; Peterson, K.J.; Schubert, M. microRNA complements in deuterostomes: Origin and evolution of microRNAs. Evol. Dev. 2011, 13, 15-27. [CrossRef] [PubMed]

203. França, G.S.; Vibranovski, M.D.; Galante, P.A. Host gene constraints and genomic context impact the expression and evolution of human microRNAs. Nat. Commun. 2016, 7, 11438. [CrossRef] [PubMed]

204. Sun, Q.; Song, Y.J.; Prasanth, K.V. One locus with two roles: MicroRNA-independent functions of microRNA-host-gene locusencoded long noncoding RNAs. Wiley Interdiscip. Rev. RNA 2021, 12, e1625. [CrossRef]

205. Li, Z.; Huang, H.; Chen, P.; He, M.; Li, Y.; Arnovitz, S.; Jiang, X.; He, C.; Hyjek, E.; Zhang, J.; et al. miR-196b directly targets both HOXA9/MEIS1 oncogenes and FAS tumour suppressor in MLL-rearranged leukaemia. Nat. Commun. 2012, 3, 688. [CrossRef] [PubMed]

206. Hall, D.P.; Cost, N.G.; Hegde, S.; Kellner, E.; Mikhaylova, O.; Stratton, Y.; Ehmer, B.; Abplanalp, W.A.; Pandey, R.; Biesiada, J.; et al. TRPM3 and miR-204 establish a regulatory circuit that controls oncogenic autophagy in clear cell renal cell carcinoma. Cancer Cell 2014, 26, 738-753. [CrossRef]

207. Miele, E.; Po, A.; Mastronuzzi, A.; Carai, A.; Besharat, Z.M.; Pediconi, N.; Abballe, L.; Catanzaro, G.; Sabato, C.; De Smaele, E.; et al. Downregulation of miR-326 and its host gene $\beta$-arrestin1 induces pro-survival activity of E2F1 and promotes medulloblastoma growth. Mol. Oncol. 2021, 15, 523-542. [CrossRef] [PubMed]

208. Herbst, F.; Lang, T.J.L.; Eckert, E.S.P.; Wünsche, P.; Wurm, A.A.; Kindinger, T.; Laaber, K.; Hemmati, S.; Hotz-Wagenblatt, A.; Zavidij, O.; et al. The balance between the intronic miR-342 and its host gene Evl determines hematopoietic cell fate decision. Leukemia 2021. [CrossRef]

209. Peperstraete, E.; Lecerf, C.; Collette, J.; Vennin, C.; Raby, L.; Völkel, P.; Angrand, P.O.; Winter, M.; Bertucci, F.; Finetti, P.; et al. Enhancement of breast cancer cell aggressiveness by lncRNA H19 and its mir-675 derivative: Insight into shared and different actions. Cancers 2020, 12, 1730. [CrossRef]

210. Wang, W.; Zhou, R.; Wu, Y.; Liu, Y.; Su, W.; Xiong, W.; Zeng, Z. PVT1 promotes cancer progression via microRNAs. Front. Oncol. 2019, 9, 609. [CrossRef] [PubMed]

211. Jones, M.F.; Li, X.L.; Subramanian, M.; Shabalina, S.A.; Hara, T.; Zhu, Y.; Huang, J.; Yang, Y.; Wakefield, L.M.; Prasanth, K.V.; et al. Growth differentiation factor-15 encodes a novel microRNA 3189 that functions as a potent regulator of cell death. Cell Death Differ. 2015, 22, 1641-1653. [CrossRef]

212. Floros, K.V.; Lochmann, T.L.; Hu, B.; Monterrubio, C.; Hughes, M.T.; Wells, J.D.; Morales, C.B.; Ghotra, M.S.; Costa, C.; Souers, A.J.; et al. Coamplification of miR-4728 protects HER2-amplified breast cancers from targeted therapy. Proc. Natl. Acad. Sci. USA 2018, 115, E2594-E2603. [CrossRef]

213. Quah, S.; Holland, P.W. The Hox cluster microRNA miR-615: A case study of intronic microRNA evolution. EvoDevo $2015,6,31$. [CrossRef] [PubMed]

214. Godínez-Rubí, M.; Ortuño-Sahagún, D. miR-615 fine-tunes growth and development and has a role in cancer and in neural repair. Cells 2020, 9, 1566. [CrossRef]

215. Liu, J.; Jia, Y.; Jia, L.; Li, T.; Yang, L.; Zhang, G. MicroRNA 615-3p inhibits the tumor growth and metastasis of NSCLC via inhibiting IGF2. Oncol. Res. 2019, 27, 269-279. [CrossRef] [PubMed] 
216. Wang, J.; Liu, L.; Sun, Y.; Xue, Y.; Qu, J.; Pan, S.; Li, H.; Qu, H.; Wang, J.; Zhang, J. miR-615-3p promotes proliferation and migration and inhibits apoptosis through its potential target CELF2 in gastric cancer. Biomed. Pharmacother. 2018, 101, 406-413. [CrossRef] [PubMed]

217. Yan, T.; Ooi, W.F.; Qamra, A.; Cheung, A.; Ma, D.; Sundaram, G.M.; Xu, C.; Xing, M.; Poon, L.; Wang, J.; et al. HoxC5 and miR-615-3p target newly evolved genomic regions to repress hTERT and inhibit tumorigenesis. Nat. Commun. 2018, 9, 100. [CrossRef] [PubMed]

218. Hiraki, M.; Maeda, T.; Bouillez, A.; Alam, M.; Tagde, A.; Hinohara, K.; Suzuki, Y.; Markert, T.; Miyo, M.; Komura, K.; et al. MUC1-C activates BMI1 in human cancer cells. Oncogene 2017, 36, 2791-2801. [CrossRef] [PubMed]

219. Hong, H.; An, O.; Chan, T.H.M.; Ng, V.H.E.; Kwok, H.S.; Lin, J.S.; Qi, L.; Han, J.; Tay, D.J.T.; Tang, S.J.; et al. Bidirectional regulation of adenosine-to-inosine (A-to-I) RNA editing by DEAH box helicase 9 (DHX9) in cancer. Nucleic Acids Res. 2018, 46, 7953-7969. [CrossRef] [PubMed]

220. Fisher, M.L.; Balinth, S.; Mills, A.A. p63-related signaling at a glance. J. Cell Sci. 2020, 133, jcs228015. [CrossRef]

221. Gatti, V.; Fierro, C.; Annicchiarico-Petruzzelli, M.; Melino, G.; Peschiaroli, A. $\Delta$ Np63 in squamous cell carcinoma: Defining the oncogenic routes affecting epigenetic landscape and tumour microenvironment. Mol. Oncol. 2019, 13, 981-1001. [CrossRef]

222. Huang, Y.; Jeong, J.S.; Okamura, J.; Sook-Kim, M.; Zhu, H.; Guerrero-Preston, R.; Ratovitski, E.A. Global tumor protein p53/p63 interactome: Making a case for cisplatin chemoresistance. Cell Cycle 2012, 11, 2367-2379. [CrossRef] [PubMed]

223. Kim, K.H.; Cho, E.G.; Yu, S.J.; Kang, H.; Kim, Y.J.; Kim, S.H.; Lee, T.R. $\Delta$ Np63 intronic miR-944 is implicated in the $\Delta$ Np63mediated induction of epidermal differentiation. Nucleic Acids Res. 2015, 43, 7462-7479. [CrossRef] [PubMed]

224. Kim, Y.J.; Lee, J.H.; Jin, S.; Kim, J.H.; Kim, S.H. Primate-specific miR-944 activates p53-dependent tumor suppression in human colorectal cancers. Cancer Lett. 2019, 440-441, 168-179. [CrossRef] [PubMed] 